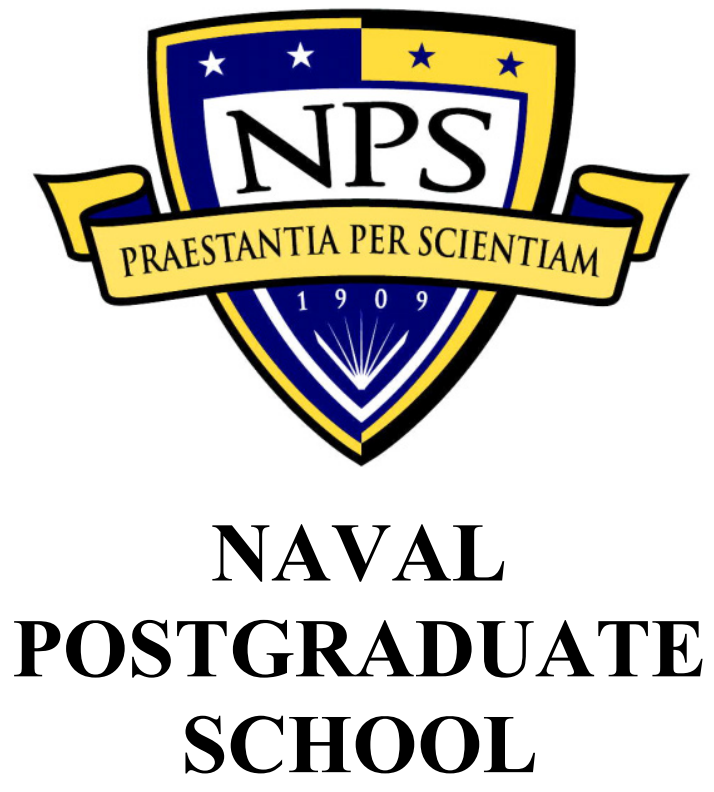

MONTEREY, CALIFORNIA

JOINT APPLIED PROJECT

DEVELOPMENT OF A NAVAL

SUPPLY SYSTEMS COMMAND

ACQUISITION SUPPLEMENT-
A BUSINESS PRACTICE IMPROVEMENT

September 2015

By: Annette Stevenson

Advisors: Charles K. Pickar

Clarence M. Belton

Approved for public release; distribution is unlimited 
THIS PAGE INTENTIONALLY LEFT BLANK 

searching existing data sources, gathering and maintaining the data needed, and completing and reviewing the collection of information. Send comments regarding this burden estimate or any other aspect of this collection of information, including suggestions for reducing this burden, to Washington headquarters Services, Directorate for Information Operations and Reports, 1215 Jefferson Davis Highway, Suite 1204, Arlington, VA 22202-4302, and to the Office of Management and Budget, Paperwork Reduction Project (0704-0188) Washington DC 20503.

\begin{tabular}{|c|c|c|}
\hline 1. AGENCY USE ONLY (Leave blank) & $\begin{array}{l}\text { 2. REPORT DATE } \\
\text { September } 2015\end{array}$ & $\begin{array}{l}\text { PORT TYPE AND DATES COVERED } \\
\text { Joint Applied Project }\end{array}$ \\
\hline \multicolumn{2}{|c|}{$\begin{array}{l}\text { 4. TITLE AND SUBTITLE } \\
\text { DEVELOPMENT OF A NAVAL SUPPLY SYSTEMS COMMAND } \\
\text { ACQUISITION SUPPLEMENT_-A BUSINESS PRACTICE IMPROVEMENT }\end{array}$} & 5. FUNDING NUMBERS \\
\hline \multicolumn{3}{|l|}{ 6. AUTHOR(S) Stevenson, Annette } \\
\hline \multicolumn{2}{|c|}{$\begin{array}{l}\text { 7. PERFORMING ORGANIZATION NAME(S) AND ADDRESS(ES) } \\
\text { Naval Postgraduate School } \\
\text { Monterey, CA } 93943-5000\end{array}$} & $\begin{array}{l}\text { 8. PERFORMING ORGANIZATION } \\
\text { REPORT NUMBER }\end{array}$ \\
\hline \multicolumn{2}{|c|}{$\begin{array}{l}\text { 9. SPONSORING /MONITORING AGENCY NAME(S) AND ADDRESS(ES) } \\
\text { N/A }\end{array}$} & $\begin{array}{l}\text { 10. SPONSORING/MONITORING } \\
\text { AGENCY REPORT NUMBER }\end{array}$ \\
\hline
\end{tabular}

11. SUPPLEMENTARY NOTES The views expressed in this thesis are those of the author and do not reflect the official policy or position of the Department of Defense or the U.S. Government. IRB Protocol number N/A

\begin{tabular}{l|l} 
12a. DISTRIBUTION / AVAILABILITY STATEMENT & 12b. DISTRIBUTION CODE
\end{tabular}

Approved for public release; distribution is unlimited

\section{ABSTRACT (maximum 200 words)}

The Naval Supply Systems Command (NAVSUP) must streamline its method of providing acquisition-related procedures, guidance, and instructions to its contracting workforce. NAVSUP's supplemental guidance to the Federal Acquisition Regulation (FAR), Defense Federal Acquisition Regulation Supplement (DFARS), and Naval Marine Corps Acquisition Regulation Supplement (NMCARS) is currently published in 142 policy letters and 13 directives. NAVSUP's current process of providing policy and guidance via dissemination of 155 individual documents is an inefficient method of communicating contracting policy and guidance to its acquisition workforce. Consolidation and organization of the information contained in these documents into a single acquisition supplement will provide the contracting workforce with an efficient method of accessing needed information when awarding and administering contracts in support of assigned logistics support functions and acquisitions related to NAVSUP's unique contracting authorities. It will also improve the NAVSUP Contracting Management Directorate's ability to efficiently communicate acquisition policy, guidance, and instructions to its acquisition workforce. This business practice improvement effort will improve communication between the NAVSUP Contracting Management Directorate's policy team, decision makers and contracting workforce; increase workplace productivity; and provide the acquisition workforce an efficient resource for obtaining NAVSUP supplemental guidance to the FAR, DFARS, and NMCARS.

\begin{tabular}{|c|c|}
\hline \multicolumn{2}{|c|}{$\begin{array}{l}\text { 14. SUBJECT TERMS } \\
\text { acquisition supplement, acquisition policy }\end{array}$} \\
\hline $\begin{array}{l}\text { 17. SECURITY } \\
\text { CLASSIFICATION OF } \\
\text { REPORT Unclassified }\end{array}$ & $\begin{array}{l}\text { 18. SECURITY } \\
\text { CLASSIFICATION OF THIS } \\
\text { PAGE } \quad \text { Unclassified }\end{array}$ \\
\hline
\end{tabular}

NSN 7540-01-280-5500

\begin{tabular}{|l|l|}
\hline & $\begin{array}{l}\text { 15. NUMBER OF } \\
\text { PAGES } \\
\end{array}$ \\
\cline { 2 - 2 } & \multicolumn{1}{|c|}{75} \\
\hline $\begin{array}{l}\text { 16. PRICE CODE } \\
\text { CLASSIFICATION OF } \\
\text { ABSTRACT } \\
\text { Unclassified }\end{array}$ & $\begin{array}{l}\text { 20. LIMITATION OF } \\
\text { ABSTRACT }\end{array}$ \\
\hline
\end{tabular}

Standard Form 298 (Rev. 2-89)

Prescribed by ANSI Std. 239-18 
THIS PAGE INTENTIONALLY LEFT BLANK 
Approved for public release; distribution is unlimited

\title{
DEVELOPMENT OF A NAVAL SUPPLY SYSTEMS COMMAND ACQUISITION SUPPLEMENT-A BUSINESS PRACTICE IMPROVEMENT
}

\author{
Annette Stevenson, Civilian, Department of the Navy \\ B.S., Columbia College, 2005 \\ Submitted in partial fulfillment of the requirements for the degree of \\ MASTER OF SCIENCE IN CONTRACT MANAGEMENT \\ from the \\ NAVAL POSTGRADUATE SCHOOL \\ September 2015
}

\author{
Author: Annette Stevenson \\ Approved by: $\quad$ Charles K. Pickar, Ph.D. \\ Advisor \\ Clarence M. Belton \\ Co-Advisor \\ William R. Gates, Ph.D. \\ Dean, Graduate School of Business and Public Policy
}


THIS PAGE INTENTIONALLY LEFT BLANK 


\title{
DEVELOPMENT OF A NAVAL SUPPLY SYSTEMS COMMAND ACQUISITION SUPPLEMENT-A BUSINESS PRACTICE IMPROVEMENT
}

\begin{abstract}
The Naval Supply Systems Command (NAVSUP) must streamline its method of providing acquisition-related procedures, guidance, and instructions to its contracting workforce. NAVSUP's supplemental guidance to the Federal Acquisition Regulation (FAR), Defense Federal Acquisition Regulation Supplement (DFARS), and Naval Marine Corps Acquisition Regulation Supplement (NMCARS) is currently published in 142 policy letters and 13 directives. NAVSUP's current process of providing policy and guidance via dissemination of 155 individual documents is an inefficient method of communicating contracting policy and guidance to its acquisition workforce. Consolidation and organization of the information contained in these documents into a single acquisition supplement will provide the contracting workforce with an efficient method of accessing needed information when awarding and administering contracts in support of assigned logistics support functions and acquisitions related to NAVSUP's unique contracting authorities. It will also improve the NAVSUP Contracting Management Directorate's ability to efficiently communicate acquisition policy, guidance, and instructions to its acquisition workforce. This business practice improvement effort will improve communication between the NAVSUP Contracting Management Directorate's policy team, decision makers and contracting workforce; increase workplace productivity; and provide the acquisition workforce an efficient resource for obtaining NAVSUP supplemental guidance to the FAR, DFARS, and NMCARS.
\end{abstract}


THIS PAGE INTENTIONALLY LEFT BLANK 


\section{TABLE OF CONTENTS}

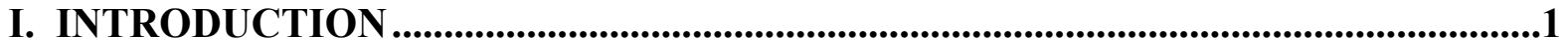

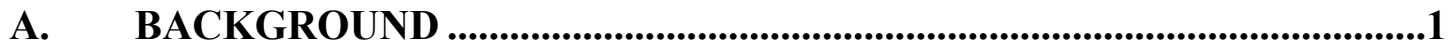

1. The Naval Supply Systems Command ...................................................1

2. Acquisition Regulations and Supplements ..............................................3

B. PURPOSE OF PROJECT.....................................................................4

C. RESEARCH QUESTIONS ...............................................................................

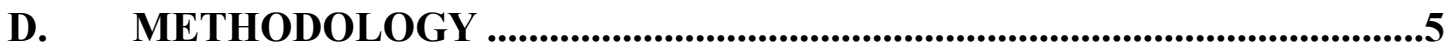

E. BENEFITS AND LIMITATIONS............................................................6

F. ORGANIZATION OF THE REPORT......................................................7

G. SUMMARY .........................................................................................................7

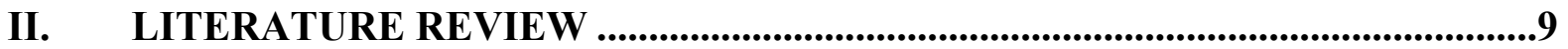

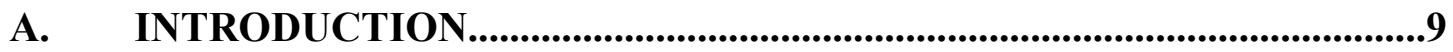

B. THE DEFENSE ACQUISITION REGULATION SYSTEM .......................9

1. The Federal Acquisition Regulation.......................................................9

2. The Defense Federal Acquisition Regulation Supplement...............10

3. Other Acquisition Regulation Supplements ........................................10

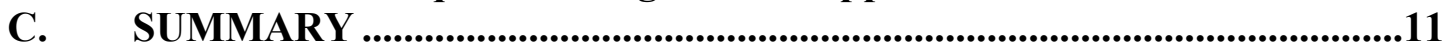

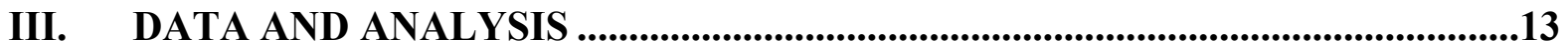

A. NAVSUP INSTRUCTIONS.............................................................................13

B. NAVSUP POLICY LETTERS ......................................................................19

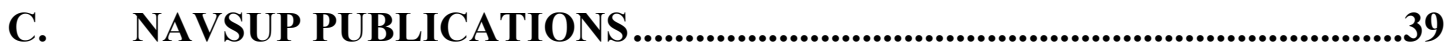

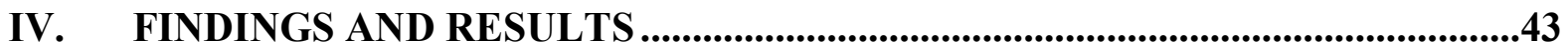

V. CONCLUSION AND RECOMMENDATIONS .................................................45

A. CONCLUSION ............................................................................................45

B. RECOMMENDATIONS................................................................................46

C. PROPOSED ACQUISITION SUPPLEMENT ...........................................47

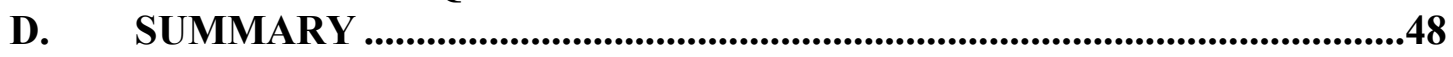

APPENDIX. ACQUISITION SUPPLEMENT TEMPLATE ............................................49

LIST OF REFERENCES......................................................................................................55

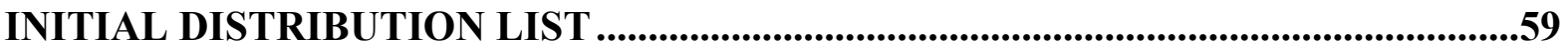


THIS PAGE INTENTIONALLY LEFT BLANK 


\section{LIST OF TABLES}

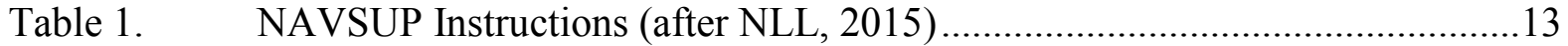

Table 2. Policy Letters Applicable to NAVSUP NFCS (after NLL, 2015).................21

Table 3. DON SAP Policy Letters (after NLL, 2015) ...........................................28

Table 4. Obsolete/Superseded Policy Letters (after NLL, 2015)................................ 31

Table 5. Relevant NAVSUP Policy Letters (after NLL, 2015) ....................................

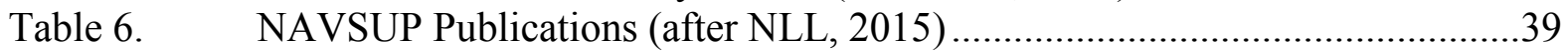

Table 7. NAVSUP Acquisition Supplement Development Process ............................47 
THIS PAGE INTENTIONALLY LEFT BLANK 


\section{LIST OF ACRONYMS AND ABBREVIATIONS}

$\begin{array}{ll}\text { ACOM } & \text { Assistant Commander for Contracting } \\ \text { CFR } & \text { Code of Federal Regulation } \\ \text { COMNAVSYSCOM } & \text { Commander, Naval Supply Systems Command } \\ \text { COR } & \text { Contracting Officer Representative } \\ \text { EBUSOPSOFFINST } & \text { eBusiness Operations Instruction } \\ \text { DAR } & \text { Defense Acquisition Regulation } \\ \text { DARS } & \text { Defense Acquisition Regulation System } \\ \text { DASN } & \text { Deputy Assistant Secretary of the Navy } \\ \text { DAWIA } & \text { Defense Acquisition Workforce Improvement Act } \\ \text { DFARS } & \text { Defense Federal Acquisition Regulation Supplement } \\ \text { DOD } & \text { Department of Defense } \\ \text { DON } & \text { Department of the Navy } \\ \text { DPAP } & \text { Defense Procurement and Acquisition Policy } \\ \text { ERP } & \text { Enterprise Resource Planning } \\ \text { FAR } & \text { Federal Acquisition Regulation } \\ \text { FLC } & \text { Fleet Logistic Center } \\ \text { GLS } & \text { Global Logistics Support } \\ \text { GSA } & \text { General Services Administration } \\ \text { HCA } & \text { Head of the Contracting Activity } \\ \text { NAVCOMPT } & \text { Navy Comptroller } \\ \text { NAVSUP } & \text { Naval Supply Systems Command } \\ \text { NAVSUPINST } & \text { Naval Supply Systems Command Instruction } \\ \text { NDAA } & \text { National Defense Authorization Act } \\ \text { NEXCOM } & \text { Navy Exchange Command } \\ \text { NFCS } & \text { Navy Field Contracting System } \\ \text { NLL } & \text { Naval Logistics Library } \\ \text { NMCARS } & \text { Navy and Marine Corps Acquisition Regulation Supplement } \\ & \end{array}$


NMLC

PGI

PPMAP

RCP

SME
Naval Medical Logistics Command

Procedures, Guidance, and Information

Procurement Performance Management Assessment Program

Request for Contractual Procurement

Subject Matter Expert 


\section{ACKNOWLEDGMENTS}

I would like to thank my advisors, Dr. Charles Pickar and Mr. Clarence Belton, for their guidance. This project would not have been possible without the support of these advisors and the NAVSUP Headquarters Contract Management Directorate. I would like to thank the entire Contract Management Directorate staff for their support. I would also like to acknowledge Mr. Frank Duggan of the Naval Sea Logistics Center, and thank him for being understanding during the final weeks of this project completion. Finally, I thank my husband, Edward, and my children, Jasmine and Jordan, for patience and support while sacrificing family time that is invaluable, especially for military families like ours. 
THIS PAGE INTENTIONALLY LEFT BLANK

xiv 


\section{INTRODUCTION}

\section{A. BACKGROUND}

\section{The Naval Supply Systems Command}

The Naval Supply Systems Command's (NAVSUP) mission is to deliver sustained global logistics and quality-of-life support to the Navy and the joint warfighter. (NAVSUP, n.d., para 1). The NAVSUP and Navy Supply Corps teams, which include a diverse group of more than 25,000 civilian and military personnel, "form a network of professionals who deliver products and services to customers in the fleet and across the world" ("Senior Contracting Experts," 2014, para. 9). Together, they "oversee a diverse portfolio, including supply chain management for material support to Navy, Marine Corps, joint and coalition partners, supply operations, conventional ordinance, contracting, resale, fuel transportation, security assistance, husbanding, and quality-of-life issues for our naval forces, including food service, postal services, Navy Exchanges, and movement of household goods" ("Senior Contracting Experts," 2014, para. 9). The NAVSUP contracting workforce strives to provide "top-notch support to the warfighter" (“Senior Contracting Experts," 2014, para. 9).

The Commander, Naval Supply Systems Command (COMNAVSYSCOM) is the Head of the Contracting Activity (HCA) for the Navy Field Contracting System (NFCS) (NAVSUP, 2012). The NFCS includes Navy contracting activities exercising contracting authority derived from COMNAVSUPSYSCOM as HCA, plus the Navy Exchange Command (NEXCOM). As HCA, COMNAVSYSCOM has overall responsibility for management and oversight of delegated contracting authority within the organization and activities whose authority is derived from the HCA.

The NAVSUP Contracting Management Directorate, located at NAVSUP Headquarters, Mechanicsburg, Pennsylvania, executes HCA and headquarters authority for contracting policy matters, operational oversight, and specific approval actions. The Directorate manages the NFCS, which includes contracting activities with contracting authority delegated from the COMNAVSYSCOM. This includes the NAVSUP Weapons 
Systems Support activity; Fleet Logistics Centers (FLCs) located in Florida, Virginia, Hawaii, California, Washington, Japan, and Italy; Commander, Joint Task Force-Horn of Africa; Navy Exchange Command; Naval Oceanographic Office; Naval Medical Logistics Command; and contracting activities with purchase card authority. NAVSUP, through the NFCS, is responsible for "procuring all supplies and services for noncontracting Navy activities, offices, or commands for which no other HCA is delegated contracting authority" (NMCARS, 2015). The core business of activities deriving their contracting authority from COMNAVSUPSYSCOM as HCA is to deliver combat capability through logistics in support of Navy customers outside the cognizance of other Navy HCAs.

The NAVSUP Assistant Commander for Contracting (ACOM), Contracting Management Directorate, is "the strategic leader for the NAVSUP contracting community and is tasked with providing a framework for the delivery of contracting services" across the NFCS. The ACOM for contracting serves as the "HCA principal staff for contracting policy matters, operational review and specific approval actions, and acts for the HCA in the management of contracting and purchasing matters under the purview of NAVSUP" (NAVSUP Contracting Management, n.d., para 1). The NAVSUP Contracting Management Directorate's mission is to "provide contracting support that allows NAVSUP to deliver sustained weapons support, global logistics and quality-oflife support, enabling the Navy to be ready to fight and responsibly employ resources" (Bennington, 2015).

The NAVSUP Contracting Management Directorate supports and elevates capabilities of its contracting workforce by providing management and technical support, with emphasis on procurement process management, strategic sourcing, end-to-end process integration, HCA oversight, services contracts management, and procurement policy and guidance. Support includes issuance of acquisition policy and guidance to the contracting workforce when supplemental information to the FAR, DFARS, and Naval Marine Corps Acquisition Regulation Supplement (NMCARS) are necessary. Central repositories for NAVSUP's policy letters and directives include the Naval Logistics Library (NLL) and the Directorate's Contracting Knowledge website. 


\section{Acquisition Regulations and Supplements}

The Defense Acquisition Regulations System (DARS) creates and maintains Department of Defense (DOD) acquisition regulations that include rules and guidance to facilitate the acquisition workforce as they procure supplies and services. "The FAR was established to codify uniform policies for acquisition of supplies and services by executive agencies" (“Acquisition Regulations," n.d., para 1), and is the responsibility of the Administrator of General Services, the Secretary of Defense, and the Administrator for the National Aeronautics and Space Administration. The DFARS establishes uniform DOD policies and procedures implementing and supplementing the FAR. The DARS office is used to create and maintain the FAR and the DFARS.

"The NMCARS establishes uniform Department of the Navy (DON) policies and procedures implementing and supplementing the FAR and the DFARS. It is prepared, issued, and maintained pursuant to the authority of Secretary of the Navy Instruction (SECNAVINST) 5400.15" (NMCAR, 2015). The NMCARS “contains mandatory acquisition policies and procedures, including delegations of authority and assignment of responsibilities. It also addresses administrative matters including procedures for processing documents for higher level approval, internal reporting requirements, and discretionary practices" (Policy \& Guidance, n.d., p. 1.). The NMCARS applies to all DON Activities; however it does not include supplemental NAVSUP guidance or address NAVSUP specific administrative matters that are necessary for execution of NAVSUP delegated authority.

As supplemental guidance to the FAR, DFARS, and NMCARS, NAVSUP issues acquisition policy, guidance, and information via policy letters, instructions, and publications. Over the years, the number of NAVSUP issued policy letters, instructions, and publications has grown immensely, resulting in information necessary for the acquisition workforce being dispersed within over 100 different documents that have become administratively burdensome and an inefficient method of communicating acquisition policy, guidance, and information to the workforce. 
This current business practice of disseminating procurement policy and guidance that supplements the FAR, DFARS, and NMCARS via policy letters and directives has resulted in the sum of 155 acquisition related documents that are available to the contracting workforce by searching the NLL and NAVSUP's Contracting Knowledge website. NAVSUP's acquisition workforce must research the FAR, DFARS, NMCARS, and look into 155 places to review NAVSUP policy letters and directives for information and guidance necessary to conduct NAVSUP business.

\section{B. PURPOSE OF PROJECT}

The NAVSUP Contracting Management Directorate's primary method of communicating acquisition-related procedures, guidance, and information to its contracting workforce is through issuance of NAVSUP policy letters and directives. The workforce must look in each individual policy letter and directive when needed. In order to retrieve information, they must look in up to 155 places, rather than a central repository. The NAVSUP acquisition workforce should have one central repository, like an acquisition supplement, for accessing NAVSUP policy letters and directives. The current business practice is both ineffective and inefficient.

The objective of this project is to streamline NAVSUP's process for communicating acquisition-related procedures, guidance, and information to its contracting workforce and to improve a business practice through initiation of the development of a NAVSUP Acquisition Supplement. This product will serve as a supplement to the FAR, DFARS, and NMCARS, and will consolidate NAVSUP's supplemental acquisition policy, guidance and information into a single document. The supplement will eliminate the need for NAVSUP's contracting workforce to go through the cumbersome process of locating and reviewing multiple policy letters and directives to obtain supplemental FAR, DFARS, and NMCARS information and guidance and ensure that supplemental guidance is easily accessible. This project will significantly reduce the number of policy letters and directives required and streamline the process for updating and maintaining acquisition related policies, procedures, directives, and FAR, DFARS, and NMCARS supplemental guidance. The NAVSUP Acquisition Supplement will be a 
primary resource for the NAVSUP acquisition workforce to obtain NAVSUP's supplemental guidance to the FAR, DFARS, and NMCARS. The result will be a business practice improvement that will streamline NAVSUPSYSCOM's method of communicating acquisition related procedures, guidance and instructions to its contracting workforce.

\section{RESEARCH QUESTIONS}

This research seeks to answer the following questions:

Primary

1. How can NAVSUP effectively and efficiently provide supplemental FAR, DFARS, and NMCARS guidance, and communicate NAVSUP acquisition related policy and information to the acquisition workforce?

Secondary

2. What are best practices across DOD on disseminating information that implement and supplement to FAR, DFARS, and NMCARS regulations and guidance, and communicating policy and guidance necessary to conduct business at agency and component levels?

\section{METHODOLOGY}

The approach to accomplishing this project includes evaluation of NAVSUP's current process for communicating acquisition policy and guidance to its acquisition workforce, to include identification of the tools currently used to communicate the information. NAVSUP's acquisition-related policy letters and directives are reviewed to determine if the information published in those documents is current, relevant, or obsolete. The NAVSUP Contracting Management Directorate will be provided a list of NAVSUP policy letters and directives determined obsolete, so that actions can be taken to cancel and remove them from the NLL. The Directorate will also be provided a list of NAVSUP policy letters and directives determined relevant to the HCA's mission. Policy and guidance provided in policy letters and directives identified as current and relevant should be incorporated into a NAVSUP Acquisition Supplement. This report includes a recommended structure and organization of a NAVSUP Acquisition Supplement. The NAVSUP Contracting Management Directorate will be responsible for ensuring that 
relevant acquisition policies, guidance, and information are documented in a supplement, to include phasing-in NAVSUP's acquisition-related policy letters and directives. The data used for this project is limited to the information contained in Federal, DOD, and DON acquisition regulations and supplements, and NAVSUP acquisition policy letters and directives.

\section{E. BENEFITS AND LIMITATIONS}

The information reviewed for this project will help the reader understand how acquisition rules and regulations flow down to the acquisition workforce. The information will also provide an understanding of the processes currently being used to communicate acquisition policy, guidance, and information to the acquisition workforce, and the importance of ensuring that the workforce receives the guidance they need to meet organizational objectives. There are many resources available to the acquisition workforce that provide information and guidance. However, supplemental information specific to a HCA, in addition to Federal, DOD, and DON rules and regulations, are necessary to adequately conduct the business of the organization and to meet unique requirements

Components are "responsible for establishing adequate and effective internal controls to carefully manage and closely oversee the execution of delegated contracting authority for assigned contracting mission functions" (NMCARS, 2015). Each DON HCA is delegated a unique contracting authority. To ensure compliance, consistency, transparency, quality, accountability, and responsibility in these specific areas, components should communicate policy, guidance, and information supplemental to FAR, DFARS, and NMCARS that address each unique contracting authority, to the contracting offices that support those contracting mission functions.

It is imperative that members of the acquisition workforce have tools necessary to perform their jobs. A NAVSUP acquisition regulation supplement is a tool that the Contracting Management Directorate can use to provide supplemental FAR, DFARS, and NMCARS guidance, and to set standards for the NAVSUP Enterprise consistent with those necessary to meet the command's mission objectives. The result will be a more 
efficient and effective method of making supplemental acquisition policy, guidance, and information specific to NAVSUP's delegated contracting authority accessible to the acquisition workforce.

The information reviewed for the purpose of this project was limited to Federal, DOD, and DON laws, rules and regulations, and information obtained from DON HCAs. Organizational human subject research was not used for this project and no interviews were conducted.

\section{F. ORGANIZATION OF THE REPORT}

This report is organized into five chapters. Chapter II provides information on the literature surveyed and evaluated for this report. Relevant sources, including the FAR and DFARS, are surveyed. This chapter also provides an overview of literature reviewed on the NMCARS, other acquisition regulations, articles, and other relevant sources. Chapter III presents the data to be analyzed and the analysis of the data. Chapter IV presents the findings and Chapter $\mathrm{V}$ provides the conclusion, recommendation, and summary of the research.

\section{G. SUMMARY}

This chapter introduced NAVSUP's contracting mission and the support that the NAVSUP Contracting Management Directorate provides to help support that mission. It identified roles and responsibilities of the Contracting Management Directorate, to include ensuring that its acquisition workforce has access to the resources necessary to successfully complete the mission. Background information on availability of and accessibility to the various resources that support the acquisition workforce is also provided.

This chapter further discussed the current process of communicating supplemental acquisition information to the acquisition workforce and the development of a NAVSUP acquisition supplement to streamline its method of providing acquisition related procedures, guidance, and instructions to its acquisition workforce. The method to be used to complete the project, and the benefits and limitations were also addressed. 
Chapter II contains literature reviews of source documents relevant to supporting the acquisition workforce. 


\section{LITERATURE REVIEW}

\section{A. INTRODUCTION}

Organizations have a responsibility to ensure that contracting operations are conducted as required by applicable procurement laws, regulations, and policies. "The Director of Defense Procurement, by delegation from the Secretary of Defense and the Under Secretary of Defense (Acquisition, Technology, and Logistics) (USD (AT\&L)) is responsible for developing, coordinating, issuing, and maintaining the FAR, DFARS, and supplementing DOD regulations and acting for the USD (AT\&L) in the administration of the FAR, DFARS, and any supplementing DOD regulations" (DFARS Operating Guide, 2015, p. 3).

\section{B. THE DEFENSE ACQUISITION REGULATION SYSTEM}

\section{The Federal Acquisition Regulation}

The FAR (2015) is an acquisition regulation that provides uniform acquisition policies and procedures "for use by Federal Executive agencies in their acquisition of supplies and services." It takes precedence over all implementing agency or component regulations. The FAR is often referred to by members of the acquisition workforce as the "contracting bible." It is designed to be user friendly for members of government acquisition, although it has been said to be quite the opposite. It is "divided into subchapters, parts (each of which covers a separate aspect of acquisition), subparts, sections, and subsections. The numbering system permits identification of every FAR paragraph" (FAR 2015). The main categories or types of information presented in the FAR are rules, guidance, and solicitation provisions and contract clauses. New hires to the acquisition workforce, 1102 series, are required to attend a four-week FAR Fundamentals course (CON 090), at a Defense Acquisition University (DAU) residence location ("Core Certification Standards," n.d., p. 1). The course provides a total immersion into the FAR. It provides students with the skills that will enable them to research acquisition issues, read and interpret guidance provided in the FAR, and to apply those regulations. 
"The FAR is prepared, issued, and maintained jointly by the Secretary of Defense, the Administrator of General Services, and the Administrator, National Aeronautics and Space Administration, under their several statutory authorities and is contained within Chapter 1 of Title 48 of the Code of Federal Regulations (CFR)" (FAR, 2015). It is published in three formats, daily issue of the Federal Register, Code of Federal Regulations, and loose leaf binder edition. The FAR is available at the GSA website (GSA, 2015), the Hill Air Force Base website, and http://acquisition.gov/far/index.html.

\section{The Defense Federal Acquisition Regulation Supplement}

The FAR is the primary set of rules that outline procurement policies and procedures for use by acquisition workforce professionals; however, it excludes internal agency policies and guidance. "The DFARS is used by the DOD to supplement the FAR and provide DOD-specific acquisition regulations that DOD government acquisition officials, and contractors doing business with DOD, must follow in the procurement process for supplies and services" (DCAA, n.d.). "The DFARS contains requirements of law, DOD-wide policies, delegations of FAR authorities, deviations from FAR requirements, and policies and procedures that have a significant effect on the public" (DPAP, 2015). The DAR Council is responsible for maintenance of the DFARS.

\section{Other Acquisition Regulation Supplements}

Other acquisition regulation supplements, including handbooks, guidebooks, manuals, publications, instructions, policy letters, and directives, are tools used by acquisition workforce professionals. These acquisition supplements are not stand-alone documents, but must be read together with the FAR and DFARS. They implement or supplement the FAR and DFARS and the information contained in them cannot deviate from those acquisition regulations without approval. 


\section{SUMMARY}

This chapter provided a brief synopsis of how the Defense Acquisition Regulation system provides for organization, simplicity, and uniformity in the federal acquisition process. Acquisition regulations and supplements are repositories of rules and regulations that the acquisition workforce must adhere to.

Policies beyond those contained in the FAR and DFARS are established to supplement guidance provided in them. This policy and supplemental guidance must be disseminated to all members of the acquisition process in a manner that is not burdensome or ambiguous. Policy and supplemental guidance should also be issued timely and properly communicated. 
THIS PAGE INTENTIONALLY LEFT BLANK 


\section{DATA AND ANALYSIS}

\section{A. NAVSUP INSTRUCTIONS}

Table 1 lists active NAVSUP acquisition-related instructions. The data contained in these instructions were reviewed for relevancy. The results of this data analysis are not all inclusive of revisions needed for these instructions. A more thorough review of each instruction, for accuracy and relevancy, should be completed by NAVSUP Contracting Directorate Subject Matter Experts (SMEs).

Table 1. NAVSUP Instructions (after NLL, 2015)

\begin{tabular}{|l|l|l|}
\hline \multicolumn{1}{|c|}{ Directive } & \multicolumn{1}{|c|}{ Subject } & \multicolumn{1}{c|}{$\begin{array}{c}\text { Date Issued/ } \\
\text { Received }\end{array}$} \\
\hline $\begin{array}{l}\text { NAVSUPINST } \\
\text { 4200.81G }\end{array}$ & $\begin{array}{l}\text { Naval Supply Systems Command, Navy Field Contracting } \\
\text { System Authority and Responsibility }\end{array}$ & JAN 272012 \\
\hline $\begin{array}{l}\text { NAVSUPINST } \\
\text { 4200.82F }\end{array}$ & $\begin{array}{l}\text { Procurement Management Assessment Program } \\
\text { (PPMAP) of the Navy Field Contracting System }\end{array}$ & JAN 272012 \\
\hline $\begin{array}{l}\text { NAVSUPINST } \\
\text { 4200.83H }\end{array}$ & $\begin{array}{l}\text { Naval Supply Systems Command Contracting and } \\
\text { Business Clearance Procedures and Approvals }\end{array}$ & DEC 182012 \\
\hline $\begin{array}{l}\text { NAVSUPINST } \\
\text { 4200.84K }\end{array}$ & Contract Reports & AUG 212014 \\
\hline $\begin{array}{l}\text { NAVSUPINST } \\
\text { 4200.85D }\end{array}$ & Department of the Navy Simplified Acquisition Procedures & APR 252005 \\
\hline $\begin{array}{l}\text { NAVSUPINST } \\
\text { 4200.96B }\end{array}$ & Procedures for Processing Unsolicited Proposals & NOV 242014 \\
\hline $\begin{array}{l}\text { NAVSUPINST } \\
\text { 4200.102 }\end{array}$ & NAVSUP Contracting Officer Warranting Program & AUG 222014 \\
\hline $\begin{array}{l}\text { NAVSUPINST } \\
\text { 4205.3E }\end{array}$ & Contracting Officer's Representative & MAY 272014 \\
\hline $\begin{array}{l}\text { NAVSUPINST } \\
\text { 4230.37D }\end{array}$ & Navy Contingency Contracting Program & JUN 12011 \\
\hline
\end{tabular}




\section{(1) NAVSUP Instruction 4200.81G}

The NAVSUP Instruction (NAVSUPINST) 4200.81G, Naval Supply Systems Command, Navy Field Contracting System Authority and Responsibility, implements and supplements the FAR, DFARS, and NMCARS, and communicates policy, guidance and information to the NFCS regarding the following (NAVSUP, 2012a):

- $\quad$ NAVSUP Delegated Contracting Authority and Responsibility

- $\quad$ Procedures for Requesting Contracting Authority

- $\quad$ Contracting Authority and Responsibility for Afloat Units

- $\quad$ Procedures for appointments of Contracting Officers and Ordering Officers

- $\quad$ HCA Delegations of Authority

- $\quad$ Definitions of Key Words and Terms

This instruction is relevant and necessary to ensure that responsibilities and delegations of authority to NFCS activities are clearly defined and consistent with contracting responsibilities assigned to NAVSUPSYSCOM HCA.

NAVSUPINST 4200.81G was last updated in January 2012. The information contained in this instruction should be incorporated into a NAVSUP Acquisition Supplement once it has been updated to reflect the most current policies and procedures relevant to NAVSUP NFCS authorities and responsibilities. Upon incorporation of relevant information into a NAVSUP acquisition supplement, this instruction should be cancelled.

\section{(2) NAVSUP Instruction 4200.82F}

NAVSUPINST 4200.82F, Procurement Performance Management Assessment Program (PPMAP) of the Navy Field Contracting System (NFCS), implements and supplements the FAR, DFARS, and NMCARS, communicates NAVSUP policies and procedures, and outlines responsibilities for the management execution of the PPMAP within the NFCS (NAVSUP, 2012c). This instruction applies to NAVSUP, the staffs of the PPMAP offices co-located at the NAVSUP Fleet Logistics Centers (FLCs), the NAVSUP Global Logistics Support (GLS), and the Naval Medical Logistics Command 
(NMLC). This instruction outlines policies and procedures to all NAVSUP PPMAP offices conducting PPMAP reviews of the NFCS that use appropriated funds.

The information contained in this instruction is relevant and necessary to ensure activities receiving contracting authority from NAVSUP are executing this authority in an effective and efficient manner. NAVSUP instruction $4200.82 \mathrm{~F}$ was last updated January 2012. The information contained in this instruction should be incorporated into the NAVSUP acquisition supplement once it has been updated to reflect the most current policies and procedures relevant to the PPMAP program. Upon successful incorporation of this information into an acquisition supplement, this instruction can be cancelled.

\section{(3) NAVSUP Instruction $4200.83 \mathrm{H}$}

NAVSUPINST 4200.83H, Naval Supply Systems Command Contracting and Business Clearance Procedures and Approvals, applies to all NFCS activities (excluding afloat units), including appropriated and non-appropriated funds contracting activities who receive their contracting authority from COMNAVSYSCOM (NAVSUP, 2012b). The purpose of this instruction is to supplement the FAR, DFARS, and NMCARS, establish NAVSUP contracting and business clearance procedures, and identify the approval levels required. Information and guidance communicated via this instruction includes the following:

- $\quad$ Contract Review Board Procedures

- $\quad$ Business Clearance Procedures

- Justification and Approvals Procedures

- Acquisition Planning Documentation

- $\quad$ Section 843 Determination and Findings Procedures

- $\quad$ The Peer Review Process

- $\quad$ Time and Material and Labor Hour Contracts Guidance

- $\quad$ One Offer and Negotiation of One Offer Guidance

- $\quad$ Economy Act Orders Guidance

- Ratification of Unauthorized Commitments Information and Guidance 
This instruction was last updated in December 2012. The procedures, guidance, and information contained in this instruction is relevant and should be incorporated into the NAVSUP acquisition supplement once it has been updated to reflect the most current policies and procedures relevant to NAVSUP contracting and business clearance procedures and approvals. Upon successfully incorporation of this information into an acquisition supplement, this instruction can be cancelled.

\section{(4) NAVSUP Instruction $4200.84 \mathrm{~K}$}

NAVSUPINST 4200.84K, Contract Reports, applies to NFCS activities with contracting authority delegated from COMNAVSYSCOM plus the Navy Exchange Service Command (NAVSUP, 2014a). Its purpose is to supplement the FAR, DFARS, NMCARS, Defense Procurement and Acquisition Policy (DPAP), Deputy Assistant Secretary of the Navy (DASN), the National Defense Authorization Act (NDAA), and US Central Command requirements for submittal of procurement related reports. The instruction further summarizes the required reports, and communicates NAVSUP policies and procedures for submissions. The procedures, guidance, and information contained in this instruction are relevant to NAVSUP's mission, and should be incorporated into the NAVSUP acquisition supplement. Upon successful incorporation of this information into an acquisition supplement, this instruction can be cancelled.

\section{NAVSUP Instruction 4200.85D}

NAVSUP is the DON Executive Agent for simplified acquisition policy. NAVSUPINST 4200.85D, Department of the Navy Simplified Acquisition Procedures, applies to all DON contracting offices and Fleet units using simplified acquisition procedures (NAVSUP, 2005). This instruction implements and supplements the FAR, DFARS, NMCARS, and eBusiness Operations Instruction (EBUSOPSOFFINST) 4200.1. The instruction communicates ashore simplified acquisition procedures, provides information and guidance on items requiring special approval, provides afloat simplified acquisition procedures, and information and guidance on the contingency contracting program. The information contained in this instruction cannot not be supplemented with any other guidance. 
The simplified acquisition procedures, policies, guidance, and information contained in this instruction are relevant to the Navy's mission and is used by all DON acquisition workforce professionals that use simplified acquisition procedures. Currently, this instruction is maintained by COMNAVSYSCOM, HCA and can be accessed via the NLL and NAVSUP's Contracting Knowledge website. This DON policy and guidance should be maintained reviewed and updated annually by NAVSUP, as the DON Executive Agent for simplified acquisition policy, and annexed in the NMCARS.

\section{(6) NAVSUP Instruction 4200.96B}

NAVSUPINST 4200.96B, Procedures for Processing Unsolicited Proposals, applies to NFCS activities with contracting authority delegated from COMNAVSYSCOM and the Navy Exchange Service Command. Its purpose is to supplement the FAR, DFARS, NMCARS, and provide guidance and procedures for processing unsolicited proposals submitted by prospective offerors. This instruction communicates additional guidance on submission, receipt, evaluation, and acceptance of unsolicited proposals received by NAVSUP NFCS. "Unsolicited proposals are a valuable means for Government agencies to obtain innovative and unique approaches to accomplishing their mission from sources outside of the Government" (NAVSUP, 2014d). The procedures for processing unsolicited proposals contained in this instruction are relevant to NAVSUP's mission, and should be incorporated into the NAVSUP acquisition supplement. Upon successful incorporation of this information into an acquisition supplement, this instruction can be cancelled.

\section{(7) NAVSUP Instruction 4205.3E}

NAVSUPINST 4205.3E, Contracting Officer's Representative, (NAVSUPINST 4205.3E) applies to NFCS activities with contracting authority delegated from COMNAVSYSCOM and to all requiring activities with Contracting Officer's Representatives (CORs) appointed by NFCS Procuring Contracting Officers (NAVSUP, 2014b). It supplements information and guidance contained in the FAR, DFARS, and DOD COR Handbook. It communicates NAVSUP policy for COR assignment responsibilities and provides guidance on COR appointment, qualification, limitations of 
authority, and COR oversight. The information contained in this instruction is current and relevant to NAVSUP's mission, and should be incorporated into the NAVSUP acquisition supplement. Upon successful incorporation of this information into an acquisition supplement, this instruction can be cancelled.

(8) NAVSUP Instruction 4230.37D

The Deputy Assistant Secretary of the Navy for Acquisition and Procurement has delegated NAVSUP Deputy Commander for Contracting Management as the Program Manager for the Navy's supplies and services contingency contracting program. NAVSUPINST 4230.37D, Navy Contingency Contracting Program, is applicable to designated Defense Acquisition Workforce Improvement Act (DAWIA) certified, DON Federal employees that provide operational contracting support and Navy Supply Corps Officers with 1306 contracting subspecialty or are DAWIA certified in contracting (NAVSUP, 2011a). This instruction supplements Joint Publication 4-10, DOD Directives and instructions, the FAR, and Secretary of the Navy instructions relevant to contingency contracting. It provides guidance and procedures for maintaining a viable supplies and services contingency contracting program within the DON.

This instruction was last updated in June 2011 and does not contain the most current information and guidance regarding the Navy contingency contracting program. Procedures, policies, guidance, and information contained in this instruction are relevant to the Navy's contingency contracting mission, and should be incorporated into the NAVSUP acquisition supplement once it has been updated to reflect the most current policies and procedures relevant contingency contracting. In addition to incorporation into a NAVSUP acquisition supplement, this instruction should remain active and should not be cancelled. 


\section{(9) NAVSUP Instruction $\mathbf{4 2 0 0 . 1 0 2}$}

NAVSUPINST 4200.102, NAVSUP Contracting Officer Warranting Program, applies to Contracting Officer warrants for all NFCS activities who receive their contracting authority from COMNAVSYSCOM. It supplements the FAR DFARS, and NMCARS, and DOD and NAVSUP instructions that pertain to contracting officer warrants. This instruction establishes NAVSUP "Contracting Officer Warranting Program policy for the selection, appointment, and termination of appointment of contracting officers" (NAVSUP, 2014c). This instruction was issued in August, 2014. The information contained in this instruction is current, relevant to NAVAUP's mission, and should be incorporated into a NAVSUP acquisition supplement. Upon successful incorporation of this information into an acquisition supplement, this instruction can be cancelled.

\section{B. NAVSUP POLICY LETTERS}

Tables 2, 3, 4, and 5 list NAVSUP policy letters that are available to the acquisition workforce via the NLL and NAVSUP's Contracting Knowledge Website. Table 2 lists policy letters related to large contracting policy that are applicable to NAVSUP NFCS activities. Table 3 lists policy letters related to simplified acquisition procedures that are applicable to the DON acquisition workforce when using simplified acquisition procedures. Table 4 lists the NAVSUP policy letters that were identified, based on review and analysis, as obsolete and superseded. Policy letters determined obsolete and superseded have been overcome by one or more of the following events:

- Information contained in the policy is outdated and no longer relevant

- The effective dates of the policy have passed

- Information contained in the policy letters was incorporated into applicable acquisition supplements, instructions, guides, or publications

- Class Deviation was implemented into DFARS or rescinded 
Table 5 lists the NAVSUP policy letters identified, based on review and analysis, as relevant policy. Tables 2, 3, 4, and 5 identify each existing policy letter by number, subject, and date issued. Also shown is the status of each policy letter as of April 2015. The results of this data analysis are not all inclusive of revisions needed for these policy letters. A more thorough review of each policy letter for accuracy and relevancy should be completed by NAVSUP Contracting SMEs. 
Table 2. Policy Letters Applicable to NAVSUP NFCS (after NLL, 2015)

\begin{tabular}{|c|c|c|c|c|}
\hline $\begin{array}{l}\text { Policy } \\
\text { Letter \# }\end{array}$ & Subject & $\begin{array}{l}\text { Date } \\
\text { Issued }\end{array}$ & $\begin{array}{l}\text { Current? } \\
\text { Y/N }\end{array}$ & Comments \\
\hline $11-08$ & $\begin{array}{l}\text { SELF-ASSESSMENT PLANS ACROSS THE NAVY } \\
\text { FIELD CONTRACTING SYSTEM (NFCS) }\end{array}$ & Apr-11 & $\mathrm{Y}$ & $\begin{array}{l}\text { Incorporate policy into } \\
\text { Acquisition Supplement }\end{array}$ \\
\hline $\begin{array}{c}11-04 \\
(E N C L 2)\end{array}$ & $\begin{array}{l}\text { NAVSUP ENTERPRISE FURNITURE POLICY } \\
\text { STANDARD PROCUREMENT SYSTEM ORDERING } \\
\text { GUIDANCE (ENCL } 2 \text { ) }\end{array}$ & Nov-10 & $\mathrm{Y}$ & $\begin{array}{l}\text { Incorporate policy into } \\
\text { Acquisition Supplement }\end{array}$ \\
\hline $11-04$ & $\begin{array}{l}\text { NAVSUP ENTERPRISE FURNITURE POLICY } \\
\text { STANDARD PROCUREMENT SYSTEM (SPS) } \\
\text { ORDERING GUIDANCE }\end{array}$ & Nov-10 & $\mathrm{Y}$ & $\begin{array}{l}\text { Incorporate policy into } \\
\text { Acquisition Supplement }\end{array}$ \\
\hline $11-03$ & $\begin{array}{l}\text { TRAINING PLAN FOR NON-DIRECTOR } \\
\text { (ACQUISITION CAREER MANAGEMENT (NON- } \\
\text { DACM) CONTRACTING INTERNS/CAREER LADDER } \\
\text { EMPLOYEES }\end{array}$ & Dec-10 & $\mathrm{N}$ & $\begin{array}{l}\text { Incorporate current policy } \\
\text { into Acquisition } \\
\text { Supplement }\end{array}$ \\
\hline $11-01$ & $\begin{array}{l}\text { QUALITY ASSURANCE SELF-ASSESSMENT (QASA) } \\
\text { PROGRAM }\end{array}$ & Dec-10 & $\mathrm{N}$ & Superseded \\
\hline $10-25$ & $\begin{array}{l}\text { CLASS DEVIATION AWARD FEE REDUCTION OR } \\
\text { DENIAL FOR JEOPARDIZING THE HEALTH OR } \\
\text { SAFETY OF GOVERNMENT FOR PERSONNEL }\end{array}$ & Aug-10 & $\mathrm{N}$ & $\begin{array}{l}\text { Superseded by Interim } \\
\text { Rule Effective June } 2011\end{array}$ \\
\hline $10-23$ & $\begin{array}{l}\text { UPDATED GUIDANCE FOR THE DEPARTMENT OF } \\
\text { THE NAVY ACQUISITION OF OFFICE SUPPLIES }\end{array}$ & Aug-10 & $\mathrm{Y}$ & $\begin{array}{l}\text { Incorporate policy into } \\
\text { Acquisition Supplement }\end{array}$ \\
\hline $10-18$ & $\begin{array}{l}\text { PROVISIONS OR CLAUSE USE IN COMMERCIAL } \\
\text { ITEM ACQUISITIONS }\end{array}$ & May-10 & $\mathrm{Y}$ & $\begin{array}{l}\text { Incorporate policy into } \\
\text { Acquisition Supplement }\end{array}$ \\
\hline $10-17$ & $\begin{array}{l}\text { RESOLVING CONTRACT AUDIT } \\
\text { RECOMMENDATIONS }\end{array}$ & Jun-10 & $\mathrm{Y}$ & $\begin{array}{l}\text { Incorporate policy into } \\
\text { Acquisition Supplement }\end{array}$ \\
\hline $10-13$ & $\begin{array}{l}\text { DEPARTMENT OF THE NAVY (DON) PROCESS FOR } \\
\text { COLLECTING EVALUATING AND REPORTING } \\
\text { AWARD AND INCENTIVE FEES EARNED }\end{array}$ & Apr-10 & $\mathrm{Y}$ & $\begin{array}{l}\text { Incorporate policy into } \\
\text { Acquisition Supplement }\end{array}$ \\
\hline $10-12$ & $\begin{array}{l}\text { CONTINUATION OF ESSENTIAL CONTRACTOR } \\
\text { SERVICES }\end{array}$ & Mar-10 & $\mathrm{Y}$ & $\begin{array}{l}\text { Incorporate policy into } \\
\text { Acquisition Supplement }\end{array}$ \\
\hline $10-10$ & $\begin{array}{l}\text { FEDERAL PROCUREMENT DATA SYSTEM (FPDS) } \\
\text { VERSION 1.4 CERTIFICATION AND DEPLOYMENT } \\
\text { REQUIREMENTS }\end{array}$ & Mar-10 & $\mathrm{N}$ & Obsolete \\
\hline $10-09$ & $\begin{array}{l}\text { CLASS DEVIATION TO IMPLEMENT ADDITIONAL } \\
\text { CONTRACTOR REQUIREMENTS AND } \\
\text { RESPONSIBILITIES RESTRICTING THE USE OF } \\
\text { MANDATORY ARBITRATION AGREEMENTS }\end{array}$ & Feb-10 & $\mathrm{Y}$ & $\begin{array}{l}\text { Incorporate policy into } \\
\text { Acquisition Supplement }\end{array}$ \\
\hline $10-07$ & $\begin{array}{l}\text { GUIDANCE ON REVIEWING CONTRACTOR } \\
\text { REPORTS REQUIRED BY THE AMERICAN } \\
\text { RECOVERY AND REINVESTMENT ACT OF } 2009\end{array}$ & Jan-10 & $\mathrm{N}$ & Obsolete \\
\hline $10-06$ & $\begin{array}{l}\text { NAVY GUIDANCE FOR PURCHASING JANITORIAL } \\
\text { AND SANITATION SUPPLIES }\end{array}$ & Mar-10 & $\mathrm{Y}$ & $\begin{array}{l}\text { Incorporate policy into } \\
\text { Acquisition Supplement }\end{array}$ \\
\hline $10-05$ & $\begin{array}{l}\text { CLASS DEVIATION -LIMITATIONS ON PASS- } \\
\text { THROUGH CHARGES }\end{array}$ & Jan-10 & $\mathrm{N}$ & Obsolete \\
\hline $10-02$ & $\begin{array}{l}\text { RECOVERY ACT INTERIM GUIDANCE ON } \\
\text { REVIEWING CONTRACTOR REPORTS }\end{array}$ & Oct-09 & $\mathrm{N}$ & Obsolete \\
\hline $10-01$ & $\begin{array}{l}\text { MANAGEMENT OF NAVY CONTRACTS ON DOD } \\
\text { EMALL NAVY CORRIDOR }\end{array}$ & Nov-09 & $\mathrm{Y}$ & $\begin{array}{l}\text { Incorporate policy into } \\
\text { Acquisition Supplement }\end{array}$ \\
\hline $09-28$ & SEAPORT ENHANCED PROGRAM & Aug-09 & $\mathrm{Y}$ & $\begin{array}{l}\text { Incorporate policy into } \\
\text { Acquisition Supplement }\end{array}$ \\
\hline
\end{tabular}


Table 2. Policy Letters Applicable to NAVSUP NFCS (after NLL, 2015) (continued)

\begin{tabular}{|c|c|c|c|c|}
\hline $\begin{array}{l}\text { Policy } \\
\text { Letter \# }\end{array}$ & Subject & $\begin{array}{l}\text { Date } \\
\text { Issued }\end{array}$ & $\begin{array}{l}\text { Current } \\
? \text { Y/N }\end{array}$ & Comments \\
\hline $09-27$ & $\begin{array}{l}\text { CLASS DEVIATION TO THE DFARS TO IMPLEMENT } \\
\text { DEPUTY SECRETARY OF DEFENSE } \\
\text { DETERMINATION AND FINDINGS (D\&FS) } \\
\text { REGARDING FOREIGN PARTICIPATION IN DOD } \\
\text { ACQUISITIONS IN SUPPORT OF OPERATIONS IN } \\
\text { AFGHANISTAN }\end{array}$ & Aug-09 & $\mathrm{N}$ & Obsolete \\
\hline $09-26$ & $\begin{array}{l}\text { PASSIVE RADIO FREQUENCY IDENTIFICATION } \\
\text { (RFID) DFARS COMPLIANCE REPORTING AND } \\
\text { MANDATORY TRAINING REQUIREMENT FOR } \\
\text { CONTRACTING PERSONNEL }\end{array}$ & Aug-09 & Y & \\
\hline $09-25$ & $\begin{array}{l}\text { RANDOLPH SHEPPARD ACT CONTRACT ACTION } \\
\text { REPORTING }\end{array}$ & Aug-09 & $\mathrm{Y}$ & \\
\hline $09-23$ & $\begin{array}{l}\text { INTERIM CHANGE TO NAVSUPINST } 4200.84 \mathrm{H} \text { (NEW } \\
\text { PROCESS FOR MEDIA ANNOUNCEMENTS) }\end{array}$ & Jul-09 & $\mathrm{N}$ & $\begin{array}{l}\text { Superseded by } \\
4200.84 \mathrm{k}\end{array}$ \\
\hline $09-21$ & $\begin{array}{l}\text { CLASS DEVIATION - COMMERCIAL ITEM OMNIBUS } \\
\text { CLAUSES FOR ACQUISITIONS USING STANDARD } \\
\text { PROCUREMENT SYSTEM }\end{array}$ & Jul-09 & $\mathrm{N}$ & Obsolete \\
\hline $09-19$ & $\begin{array}{l}\text { GOVERNMENT SOURCE APPROVAL REQUIRED } \\
\text { PRIOR TO AWARD (JUN 2009) (NAVSUP) }\end{array}$ & Jun-09 & Y & $\begin{array}{l}\text { Incorporate policy into } \\
\text { Acquisition Supplement. }\end{array}$ \\
\hline $09-18$ & $\begin{array}{l}\text { INTERIM CHANGE TO NAVSUP INSTRUCTION } \\
\text { 4200.83G CONTRACTING AND BUSINESS } \\
\text { CLEARANCE PROCEDURES AND APPROVALS }\end{array}$ & Oct-09 & $\mathrm{N}$ & $\begin{array}{l}\text { Superseded BY } \\
4200.83 \mathrm{H}\end{array}$ \\
\hline $09-15$ & $\begin{array}{l}\text { PROPER USE OF TIME AND MATERIAL CONTRACT } \\
\text { TYPES }\end{array}$ & May-09 & $\mathrm{N}$ & $\begin{array}{l}\text { Incorporate policy into } \\
\text { Acquisition Supplement. }\end{array}$ \\
\hline $09-13$ & $\begin{array}{l}\text { PAST PERFORMANCE INFORMATION RETRIEVAL } \\
\text { SYSTEM - STATISTICAL REPORTING (PPIRS-SR) }\end{array}$ & Mar-09 & Y & $\begin{array}{l}\text { Incorporate policy into } \\
\text { Acquisition Supplement. }\end{array}$ \\
\hline $09-10$ & $\begin{array}{l}\text { IMPLEMENTATION OF ELECTRONIC } \\
\text { SUBCONTRACTING REPORTING SYSTEM (ESRS) } \\
\text { AND REPORTING FUNCTIONS }\end{array}$ & Jan-09 & Y & $\begin{array}{l}\text { Incorporate policy into } \\
\text { Acquisition Supplement. }\end{array}$ \\
\hline 09-09 & APPOINTMENT OF COMPETITION ADVOCATES & Dec-08 & $\mathrm{N}$ & Superseded by $14-05$ \\
\hline 09-05 & $\begin{array}{l}\text { REPORTING PROFIT AND FEE STATISTICS USING } \\
\text { WEB-BASED APPLICATION }\end{array}$ & Feb-09 & Y & $\begin{array}{l}\text { Incorporate policy into } \\
\text { Acquisition Supplement. }\end{array}$ \\
\hline $09-03$ & $\begin{array}{l}\text { SPECIAL LIMITATIONS ON USE OF OTHER THAN } \\
\text { FIXED PRICE CONTRACTS FOR FOLLOW-ON AND } \\
\text { RENEWAL CONTRACTS }\end{array}$ & Feb-09 & Y & $\begin{array}{l}\text { Incorporate policy into } \\
\text { Acquisition Supplement. }\end{array}$ \\
\hline 09-01 & $\begin{array}{l}\text { REPORTING AWARDS TO THE FEDERAL } \\
\text { PROCUREMENT DATA SYSTEM - NEXT GENERATION } \\
\text { (FPDS-NG) }\end{array}$ & Oct-08 & Y & $\begin{array}{l}\text { Incorporate policy into } \\
\text { Acquisition Supplement }\end{array}$ \\
\hline $08-48$ & $\begin{array}{l}\text { DETERMINATION AND FINDINGS (D\&F) FOR PARA- } \\
\text { ARAMID FIBERS AND YARNS - QUALIFYING } \\
\text { COUNTRIES }\end{array}$ & Aug-08 & $\mathrm{N}$ & $\begin{array}{l}\text { Superseded by DFARS } \\
\text { Final Rule JUN } 2010\end{array}$ \\
\hline
\end{tabular}


Table 2. Policy Letters Applicable to NAVSUP NFCS (after NLL, 2015) (continued)

\begin{tabular}{|c|c|c|c|c|}
\hline $\begin{array}{l}\text { Policy } \\
\text { Letter \# }\end{array}$ & Subject & $\begin{array}{l}\text { Date } \\
\text { Issued }\end{array}$ & $\begin{array}{l}\text { Current? } \\
\text { Y/N }\end{array}$ & Comments \\
\hline $08-47$ & $\begin{array}{l}\text { CLASS DEVIATION FROM DFARS 237.102-71 } \\
\text { LIMITATION ON SERVICE CONTRACTS FOR } \\
\text { MILITARY FLIGHT SIMULATORS }\end{array}$ & Aug-08 & $\mathrm{N}$ & Superseded \\
\hline $08-31$ & $\begin{array}{l}\text { REQUESTS FOR AUTHORITY TO CONTRACT WITH } \\
\text { GOVERNMENT EMPLOYEES }\end{array}$ & Jul-08 & Y & $\begin{array}{l}\text { Incorporate policy into } \\
\text { Acquisition Supplement }\end{array}$ \\
\hline $08-28$ & POLICY FOR USE OF SHARED SOURCES & Jun-08 & Y & $\begin{array}{l}\text { Incorporate policy into } \\
\text { Acquisition Supplement }\end{array}$ \\
\hline $08-25$ & $\begin{array}{l}\text { INTERAGENCY ACQUISITION WITH DEPARTMENT } \\
\text { OF THE INTERIOR/ACQUISITION SERVICES } \\
\text { DIRECTORATE }\end{array}$ & May-08 & $\mathrm{N}$ & $\begin{array}{l}\text { Incorporate policy into } \\
\text { Acquisition Supplement }\end{array}$ \\
\hline $08-24$ & $\begin{array}{l}\text { REQUIREMENT TO INCLUDE THE NAVSUP } \\
\text { STANDARD CLAUSE FOR INVOICING AND PAYMENT } \\
\text { INSTRUCTIONS IN CONTRACT ACTIONS WHEN } \\
\text { WIDE AREA WORKFLOW IS THE METHOD OF } \\
\text { SUBMISSION }\end{array}$ & Apr-08 & $\mathrm{N}$ & Superseded \\
\hline $08-20$ & $\begin{array}{l}\text { AUTHORITY TO ESTABLISH TRANSPORTATION } \\
\text { SERVICES CONTRACTS }\end{array}$ & Feb-08 & Y & $\begin{array}{l}\text { Incorporate policy into } \\
\text { Acquisition Supplement }\end{array}$ \\
\hline $08-18$ & $\begin{array}{l}\text { IMPLEMENTING GUIDANCE FOR DEPARTMENT OF } \\
\text { THE NAVY ACQUISITION POLICY ON OFFICE } \\
\text { SUPPLIES (SPIRAL II) }\end{array}$ & Feb-08 & $\mathrm{N}$ & Superseded \\
\hline $08-17$ & SECTION 508 COMPLIANCE & Jan-08 & Y & $\begin{array}{l}\text { Incorporate policy into } \\
\text { Acquisition Supplement }\end{array}$ \\
\hline 08-16R1 & $\begin{array}{l}\text { IMPROVING COMMUNICATIONS DURING } \\
\text { COMPETITIVE SOURCE SELECTIONS }\end{array}$ & Apr-08 & $\mathrm{N}$ & $\begin{array}{l}\text { Superseded by DOD } \\
\text { guidelines } 2014\end{array}$ \\
\hline $08-15$ & BODY ARMOR APPROVED FOR NAVY PURCHASE & Jan-08 & $\mathrm{N}$ & $\begin{array}{l}\text { Incorporate current } \\
\text { policy into Acquisition } \\
\text { Supplement }\end{array}$ \\
\hline $08-12$ & CONTRACTING COMMUNITY MANAGEMENT PLAN & Jan-08 & $\mathrm{N}$ & $\begin{array}{l}\text { Update and maintain } \\
\text { on the NLL }\end{array}$ \\
\hline 08-09 & $\begin{array}{l}\text { IMPLEMENTATION OF SYNCHRONIZED } \\
\text { PREDEPLOYMENT AND OPERATIONAL TRACKER } \\
\text { (SPOT) }\end{array}$ & Nov-07 & $\mathrm{N}$ & Superseded \\
\hline $08-07$ & $\begin{array}{l}\text { ACCESS TO INFORMATION OTHER THAN COST AND } \\
\text { PRICING DATA WITH EXCLUSIVE } \\
\text { DISTRIBUTORS/DEALERS }\end{array}$ & Nov-07 & Y & $\begin{array}{l}\text { Incorporate policy into } \\
\text { Acquisition Supplement }\end{array}$ \\
\hline $08-02$ & $\begin{array}{l}\text { CONTENT OF DETERMINATIONS AND FINDINGS } \\
\text { (D\&F) TO PROCEED IN THE FACE OF PROTESTS TO } \\
\text { THE GENERAL ACCOUNTING OFFICE }\end{array}$ & Oct-07 & Y & $\begin{array}{l}\text { Incorporate policy into } \\
\text { Acquisition Supplement }\end{array}$ \\
\hline $07-27$ & $\begin{array}{l}\text { APPLICABILITY OF THE JAVITS-WAGNER-O'DAY ACT } \\
\text { AND THE RANDOLPH-SHEPPARD ACT TO MILITARY } \\
\text { DINING FACILITY CONTRACTS }\end{array}$ & Apr-07 & Y & $\begin{array}{l}\text { Incorporate policy into } \\
\text { Acquisition Supplement }\end{array}$ \\
\hline $07-20$ & $\begin{array}{l}\text { CONTRACTING POSTAL FUNCTIONS POLICY } \\
\text { MEMORANDUM }\end{array}$ & Apr-07 & Y & $\begin{array}{l}\text { Incorporate policy into } \\
\text { Acquisition Supplement }\end{array}$ \\
\hline $07-17$ & $\begin{array}{l}\text { ASSIGNMENT OF PROPER PROCUREMENT } \\
\text { INSTRUMENT IDENTIFICATION NUMBERS (PIINS) } \\
\text { FOR MASTER AGREEMENTS FOR THE REPAIR AND } \\
\text { ALTERATION OF VESSELS (MARAVS) AGREEMENT }\end{array}$ & Feb-07 & Y & $\begin{array}{l}\text { Incorporate policy into } \\
\text { Acquisition Supplement }\end{array}$ \\
\hline
\end{tabular}


Table 2. Policy Letters Applicable to NAVSUP NFCS (after NLL, 2015) (continued)

\begin{tabular}{|c|c|c|c|c|}
\hline $\begin{array}{l}\text { Policy } \\
\text { Letter \# }\end{array}$ & Subject & $\begin{array}{l}\text { Date } \\
\text { Issued }\end{array}$ & $\begin{array}{l}\text { Current? } \\
\text { Y/N }\end{array}$ & Comments \\
\hline $07-14$ & $\begin{array}{l}\text { SOFTWARE PROCESS IMPROVEMENT INITIATIVE } \\
\text { CONTRACT LANGUAGE }\end{array}$ & Feb-07 & Y & $\begin{array}{l}\text { Incorporate policy into } \\
\text { Acquisition Supplement }\end{array}$ \\
\hline $07-06$ & $\begin{array}{l}\text { ANTI-TERRORISM/FORCE PROTECTION MEASURES } \\
\text { FOR PROCUREMENTS SUPPORTING U.S. NAVY } \\
\text { PORT VISITS }\end{array}$ & Mar-07 & $\mathrm{Y}$ & $\begin{array}{l}\text { Incorporate policy into } \\
\text { Acquisition Supplement }\end{array}$ \\
\hline $07-03 A$ & $\begin{array}{l}\text { BASE SUPPLY CENTER STATEMENT OF WORK } \\
\text { (ENCL } 1 \text { IN WORD) }\end{array}$ & Nov-06 & $\mathrm{N}$ & $\begin{array}{l}\text { Incorporate current } \\
\text { policy into Acquisition } \\
\text { Supplement }\end{array}$ \\
\hline $07-03$ & BASE SUPPLY CENTER STATEMENT OF WORK & Nov-06 & $\mathrm{N}$ & $\begin{array}{l}\text { Incorporate current } \\
\text { policy into Acquisition } \\
\text { Supplement }\end{array}$ \\
\hline $07-02$ & $\begin{array}{l}\text { REVIEW AND DOCUMENTATION OF PERFORMANCE } \\
\text { BASED LOGISTICS (PBL) CONTRACTS }\end{array}$ & Oct-06 & $\mathrm{N}$ & $\begin{array}{l}\text { Incorporate current } \\
\text { policy into Acquisition } \\
\text { Supplement }\end{array}$ \\
\hline $07-01$ & NAVSUP/NAVFAC CONTRACTING RESPONSIBILITIES & Oct-06 & $\mathrm{N}$ & $\begin{array}{l}\text { Incorporate current } \\
\text { policy into Acquisition } \\
\text { Supplement }\end{array}$ \\
\hline $06-26$ & $\begin{array}{l}\text { INTERIM CHANGES TO THE NAVSUP CONTRACTING } \\
\text { OFFICER'S REPRESENTATIVE (COR) INSTRUCTION }\end{array}$ & & $\mathrm{N}$ & Superseded \\
\hline $06-25$ & $\begin{array}{l}\text { SPECIAL REVIEW REQUIREMENTS FOR OFFICE } \\
\text { SUPPLY CONTRACTS AND OPTIONS }\end{array}$ & Aug-06 & $\mathrm{Y}$ & $\begin{array}{l}\text { Incorporate policy into } \\
\text { Acquisition Supplement }\end{array}$ \\
\hline $06-22$ & SPS CONSOLIDATED SERVER TIME ZONE & Jun-06 & $\mathrm{N}$ & Obsolete/Cancel \\
\hline $06-17$ & AWARD FEE CONTRACTS & May-06 & $\mathrm{N}$ & $\begin{array}{l}\text { Incorporate current } \\
\text { policy into Acquisition } \\
\text { Supplement }\end{array}$ \\
\hline $06-16$ & $\begin{array}{l}\text { PURCHASE OF COMMERCIAL TRANSPORTATION } \\
\text { FOR DOD PASSENGERS WITHIN CONUS }\end{array}$ & Mar-06 & $\mathrm{N}$ & $\begin{array}{l}\text { Incorporate current } \\
\text { policy into Acquisition } \\
\text { Supplement }\end{array}$ \\
\hline $06-15$ & $\begin{array}{l}\text { USE OF APPROPRIATED FUNDS TO PURCHASE } \\
\text { FOOD AT CONFERENCES MEETINGS AND EVENTS }\end{array}$ & Mar-06 & $\mathrm{N}$ & $\begin{array}{l}\text { Incorporate current } \\
\text { policy into Acquisition } \\
\text { Supplement }\end{array}$ \\
\hline $06-12$ & $\begin{array}{l}\text { PROPOSED ADDITIONS TO THE JAVITS-WAGNER- } \\
\text { O'DAY (JWOD) PROGRAM PROCUREMENT LIST }\end{array}$ & Apr-06 & $\mathrm{N}$ & $\begin{array}{l}\text { Incorporate current } \\
\text { policy into Acquisition } \\
\text { Supplement }\end{array}$ \\
\hline $06-11$ & $\begin{array}{l}\text { USE OF MILITARY EXCHANGES FOR PHYSICAL } \\
\text { TRAINING GEAR PROCUREMENTS }\end{array}$ & Jan-06 & $\mathrm{Y}$ & $\begin{array}{l}\text { Incorporate policy into } \\
\text { Acquisition Supplement }\end{array}$ \\
\hline $06-06$ & $\begin{array}{l}\text { APPOINTMENT OF SOURCE SELECTION } \\
\text { AUTHORITIES }\end{array}$ & Jan-06 & $\mathrm{Y}$ & $\begin{array}{l}\text { Incorporate policy into } \\
\text { Acquisition Supplement }\end{array}$ \\
\hline $06-02 \mathrm{C}$ & $\begin{array}{l}\text { POLICY TO ESTABLISH AND IMPLEMENT SELF- } \\
\text { ASSESSMENT PLANS ACROSS THE NAVY FIELD } \\
\text { CONTRACTING SYSTEM (NFCS)(ENCL } 3 \text { IN WORD) }\end{array}$ & Jul-06 & $\mathrm{N}$ & Superseded by $13-009$ \\
\hline $06-02 B$ & $\begin{array}{l}\text { POLICY TO ESTABLISH AND IMPLEMENT SELF- } \\
\text { ASSESSMENT PLANS ACROSS THE NAVY FIELD } \\
\text { CONTRACTING SYSTEM (NFCS)(ENCL } 2 \text { IN WORD) }\end{array}$ & Jul-06 & $\mathrm{N}$ & Superseded by $13-009$ \\
\hline $06-02 A$ & $\begin{array}{l}\text { POLICY TO ESTABLISH AND IMPLEMENT SELF- } \\
\text { ASSESSMENT PLANS ACROSS THE NAVY FIELD } \\
\text { CONTRACTING SYSTEM (NFCS)(ENCL } 1 \text { IN WORD) }\end{array}$ & Jul-06 & $\mathrm{N}$ & Superseded 13-009 \\
\hline
\end{tabular}


Table 2. Policy Letters Applicable to NAVSUP NFCS (after NLL, 2015) (continued)

\begin{tabular}{|c|c|c|c|c|}
\hline $\begin{array}{l}\text { Policy } \\
\text { Letter \# }\end{array}$ & Subject & $\begin{array}{l}\text { Date } \\
\text { Issued }\end{array}$ & $\begin{array}{l}\text { Current? } \\
\text { Y/N }\end{array}$ & Comments \\
\hline $06-02$ & $\begin{array}{l}\text { POLICY TO ESTABLISH AND IMPLEMENT SELF- } \\
\text { ASSESSMENT PLANS ACROSS THE NAVY FIELD } \\
\text { CONTRACTING SYSTEM (NFCS) }\end{array}$ & Jul-06 & $\mathrm{N}$ & Superseded 13-009 \\
\hline $05-18$ & $\begin{array}{l}\text { INCREASED MICRO-PURCHASE THRESHOLD IN } \\
\text { SUPPORT OF HURRICANE KATRINA RESCUE AND } \\
\text { RELIEF OPERATIONS }\end{array}$ & Sep-05 & $\mathrm{N}$ & Obsolete \\
\hline $05-17 \mathrm{~A}$ & SEAPORT-E (WAIVER IN WORD) & Aug-05 & $\mathrm{Y}$ & $\begin{array}{l}\text { Incorporate policy into } \\
\text { Acquisition } \\
\text { Supplement }\end{array}$ \\
\hline $05-17$ & SEAPORT-E IMPLEMENTATION POLICY & Aug-05 & $\mathrm{Y}$ & $\begin{array}{l}\text { Incorporate policy into } \\
\text { Acquisition } \\
\text { Supplement }\end{array}$ \\
\hline $05-11$ & $\begin{array}{l}\text { TEST PROGRAM FOR STREAMLINED CONTRACT } \\
\text { CLOSE-OUT PROCEDURES FOR FIRM-FIXED ORDERS } \\
\text { AGAINST GSA FEDERAL SUPPLY SCHEDULE AND } \\
\text { INDEFINITE DELIVERY TYPE CONTRACTS }\end{array}$ & Apr-05 & $\mathrm{N}$ & Obsolete \\
\hline $05-10$ & $\begin{array}{l}\text { DON ACQUISITION POLICY ON MOBILE (CELLULAR) } \\
\text { PHONE AND DATA EQUIPMENT AND SERVICES }\end{array}$ & May-05 & Y & $\begin{array}{l}\text { Incorporate policy into } \\
\text { Acquisition } \\
\text { Supplement }\end{array}$ \\
\hline $05-02$ & SMALL BUSINESS TRAINING & Feb-05 & $\mathrm{N}$ & Obsolete \\
\hline $05-01$ & SMALL BUSINESS TRAINING & Nov-04 & $\mathrm{N}$ & Superseded \\
\hline $04-14$ & $\begin{array}{l}\text { NAVSUP NON-NAVY OWNED CRANES NON- } \\
\text { STANDARD CLAUSE }\end{array}$ & Sep-04 & $\mathrm{N}$ & $\begin{array}{l}\text { Incorporate current } \\
\text { policy into Acquisition } \\
\text { Supplement }\end{array}$ \\
\hline $04-03$ & $\begin{array}{l}\text { ACQUISITION POLICY ON FACILITATING VENDOR } \\
\text { SHIPMENTS IN THE DOD ORGANIC DISTRIBUTION } \\
\text { SYSTEM }\end{array}$ & Nov-03 & $\mathrm{N}$ & $\begin{array}{l}\text { Incorporate current } \\
\text { policy into Acquisition } \\
\text { Supplement }\end{array}$ \\
\hline $02-20$ & CLASS DEVIATION - INTEREST COSTS & May-02 & $\mathrm{N}$ & Obsolete \\
\hline $02-01$ & $\begin{array}{l}\text { AUTHORIZATION TO UTILIZE CONTINGENCY } \\
\text { OPERATIONS CONTRACTING PROCEDURES }\end{array}$ & Oct-01 & $\mathrm{N}$ & Obsolete \\
\hline $15-002$ & $\begin{array}{l}\text { NAVAL SUPPLY SYSTEMS COMMAND ENTERPRISE } \\
\text { MANDATORY USE OF REVERSE AUCTIONS }\end{array}$ & Nov-14 & $\mathrm{Y}$ & $\begin{array}{l}\text { Incorporate policy into } \\
\text { Acquisition } \\
\text { Supplement }\end{array}$ \\
\hline $14-065$ & $\begin{array}{l}\text { TEST PROGRAM FOR STREAMLINED CONTRACT } \\
\text { CLOSE-OUT }\end{array}$ & Apr-14 & $\mathrm{Y}$ & $\begin{array}{l}\text { Incorporate policy into } \\
\text { Acquisition } \\
\text { Supplement }\end{array}$ \\
\hline $14-010$ & USE OF TECHNICAL DIRECTION LETTERS & Sep-14 & $\mathrm{Y}$ & $\begin{array}{l}\text { Incorporate policy into } \\
\text { Acquisition } \\
\text { Supplement }\end{array}$ \\
\hline $14-009$ & AFLOAT AUTHORITY & Nov-14 & Y & $\begin{array}{l}\text { Incorporate policy into } \\
\text { Acquisition } \\
\text { Supplement }\end{array}$ \\
\hline $14-008$ & $\begin{array}{l}\text { REDUCING RELIANCE ON BRIDGE CONTRACTING } \\
\text { ACTIONS BY LEVERAGING USE OF ESTABLISHED } \\
\text { CONTRACTS VEHICLES }\end{array}$ & Jul-14 & Y & $\begin{array}{l}\text { Incorporate policy into } \\
\text { Acquisition } \\
\text { Supplement }\end{array}$ \\
\hline $14-005$ & APPOINTMENT OF COMPETITION ADVOCATES & Mar-14 & Y & $\begin{array}{l}\text { Incorporate policy into } \\
\text { Acquisition } \\
\text { Supplement }\end{array}$ \\
\hline
\end{tabular}


Table 2. Policy Letters Applicable to NAVSUP NFCS (after NLL, 2015) (continued)

\begin{tabular}{|c|c|c|c|c|}
\hline $\begin{array}{l}\text { Policy } \\
\text { Letter \# }\end{array}$ & Subject & $\begin{array}{l}\text { Date } \\
\text { Issued }\end{array}$ & $\begin{array}{l}\text { Current? } \\
\text { Y/N }\end{array}$ & Comments \\
\hline $14-004$ & $\begin{array}{l}\text { SPECIFYING SECURITY REQUIREMENTS - USE OF } \\
\text { FEDERAL ACQUISITION REGULATION CLAUSE } \\
52.204-2\end{array}$ & Feb-14 & Y & $\begin{array}{l}\text { Incorporate policy into } \\
\text { Acquisition Supplement }\end{array}$ \\
\hline $14-003$ & $\begin{array}{l}\text { TERMINATION FOR DEFAULT OR CAUSE REPORTING } \\
\text { IN THE FEDERAL AWARDEE PERFORMANCE AND } \\
\text { INTEGRITY INFORMATION SYSTEM }\end{array}$ & Oct-13 & $\mathrm{Y}$ & $\begin{array}{l}\text { Incorporate policy into } \\
\text { Acquisition Supplement }\end{array}$ \\
\hline 14-001 & $\begin{array}{l}\text { NAVSUP FY14 CONTRACTUAL PLANNING FOR } \\
\text { AGENCY OPERATIONS DURING GOVERNMENT } \\
\text { SHUTDOWN }\end{array}$ & Oct-13 & $\mathrm{N}$ & Obsolete \\
\hline $13-010$ & $\begin{array}{l}\text { QUALITY ASSURANCE SELF-ASSESSMENT (QASA) } \\
\text { PROGRAM }\end{array}$ & Sep-13 & Y & $\begin{array}{l}\text { Incorporate policy into } \\
\text { Acquisition Supplement }\end{array}$ \\
\hline 13-009 & $\begin{array}{l}\text { SELF ASSESSMENT PLANS ACROSS THE NAVY } \\
\text { FIELD CONTRACTING SYSTEM }\end{array}$ & Aug-13 & $\mathrm{Y}$ & $\begin{array}{l}\text { Incorporate policy into } \\
\text { Acquisition Supplement }\end{array}$ \\
\hline 13-008 & $\begin{array}{l}\text { PROCEDURES FOR ACQUIRING CONTRACT } \\
\text { LINGUIST FOREIGN LANGUAGE SUPPORT }\end{array}$ & Aug-13 & Y & $\begin{array}{l}\text { Incorporate policy into } \\
\text { Acquisition Supplement }\end{array}$ \\
\hline 13-007 & $\begin{array}{l}\text { CONTRACTOR UNCLASSIFIED ACCESS TO } \\
\text { FEDERALLY CONTROLLED FACILITIES SENSITIVE } \\
\text { INFORMATION, INFORMATION TECHNOLOGY } \\
\text { SYSTEMS OR PROTECTED HEALTH INFORMATION }\end{array}$ & Sep-13 & $\mathrm{Y}$ & $\begin{array}{l}\text { Incorporate policy into } \\
\text { Acquisition Supplement }\end{array}$ \\
\hline 13-006 & $\begin{array}{l}\text { DELEGATION OF AUTHORITY RELATING TO } \\
\text { LIMITATION ON AMOUNTS AVAILABLE FOR } \\
\text { CONTRACT SERVICES }\end{array}$ & Mar-13 & Y & $\begin{array}{l}\text { Incorporate policy into } \\
\text { Acquisition Supplement }\end{array}$ \\
\hline 13-004 & EQUIPMENT LEASE OR PURCHASE & Jun-13 & Y & $\begin{array}{l}\text { Incorporate policy into } \\
\text { Acquisition Supplement }\end{array}$ \\
\hline $13-003$ & MAINTENANCE REPAIR OPERATION SUPPLIES & Apr-13 & Y & $\begin{array}{l}\text { Incorporate policy into } \\
\text { Acquisition Supplement }\end{array}$ \\
\hline $13-002$ & $\begin{array}{l}\text { NAVAL SUPPLY SYSTEMS COMMAND ENTERPRISE } \\
\text { ACQUISITION POLICY FOR USE OF THE GLOBAL } \\
\text { BUSINESS SOLUTIONS CONTRACT FOR GENERAL } \\
\text { SUPPORT SERVICES }\end{array}$ & Nov-12 & $\mathrm{N}$ & Obsolete \\
\hline $12-17$ & $\begin{array}{l}\text { INFORMATION TECHNOLOGY PROCUREMENT } \\
\text { APPROVAL AND OVERSIGHT AUTHORITY }\end{array}$ & Oct-12 & $Y$ & $\begin{array}{l}\text { Incorporate policy into } \\
\text { Acquisition Supplement }\end{array}$ \\
\hline $12-15$ & $\begin{array}{l}\text { NAVSUP ENTERPRISE SERVICE ACQUISITION } \\
\text { REQUIREMENTS OVERSIGHT POLICY }\end{array}$ & Oct-12 & $Y$ & $\begin{array}{l}\text { Incorporate policy into } \\
\text { Acquisition Supplement }\end{array}$ \\
\hline $12-14$ & $\begin{array}{l}\text { NAVSUP ENTERPRISE CONTRACTING POLICY FOR } \\
\text { INCREASING SMALL BUSINESS OPPORTUNITIES IN } \\
\text { SERVICE ACQUISITIONS }\end{array}$ & Jul-12 & $\mathrm{Y}$ & $\begin{array}{l}\text { Incorporate policy into } \\
\text { Acquisition Supplement }\end{array}$ \\
\hline $12-13$ & $\begin{array}{l}\text { TEST PROGRAM FOR STREAMLINED CONTRACT } \\
\text { CLOSE-OUT PROCEDURES FOR FIRMFIXED ORDERS } \\
\text { AGAINST GSA FEDERAL SUPPLY SCHEDULE AND } \\
\text { INDEFINITE DELIVERY TYPE CONTRACTS }\end{array}$ & $\begin{array}{l}\text { May- } \\
12\end{array}$ & $N$ & $\begin{array}{l}\text { Incorporate current } \\
\text { policy into Acquisition } \\
\text { Supplement }\end{array}$ \\
\hline $12-12$ & $\begin{array}{l}\text { INTERIM CHANGE TO NAVSUP INSTRUCTION } \\
\text { 4200.83H CONTRACTING AND BUSINESS } \\
\text { CLEARANCE PROCEDURES AND APPROVALS }\end{array}$ & Jun-12 & $Y$ & $\begin{array}{l}\text { Incorporate policy into } \\
\text { Acquisition Supplement }\end{array}$ \\
\hline 12-09R1 & $\begin{array}{l}\text { NAVSUP ENTERPRISE POLICY FOR MANAGEMENT } \\
\text { OF UNAUTHORIZED COMMITMENT REPEAT } \\
\text { OFFENDERS - REV } 1\end{array}$ & Aug-12 & $Y$ & $\begin{array}{l}\text { Incorporate policy into } \\
\text { Acquisition Supplement }\end{array}$ \\
\hline $12-09$ & $\begin{array}{l}\text { NAVSUP ENTERPRISE CONTRACTING POLICY FOR } \\
\text { MANAGEMENT OF UNAUTHORIZED COMMITMENT } \\
\text { REPEAT OFFENDERS }\end{array}$ & Jun-12 & $\mathrm{Y}$ & $\begin{array}{l}\text { Incorporate policy into } \\
\text { Acquisition Supplement }\end{array}$ \\
\hline $12-08$ & $\begin{array}{l}\text { NAVSUP ENTERPRISE ACQUISITION POLICY FOR } \\
\text { CONTRACTING FOR CONFERENCES }\end{array}$ & Feb-12 & $\mathrm{N}$ & $\begin{array}{l}\text { Incorporate current } \\
\text { policy into Acquisition } \\
\text { Supplement }\end{array}$ \\
\hline $12-02$ & $\begin{array}{l}\text { NAVSUP IMPLEMENTATION OF DEPARTMENT OF } \\
\text { NAVY (DON) FURNITURE ACQUISITION POLICY }\end{array}$ & Oct-11 & $Y$ & $\begin{array}{l}\text { Incorporate policy into } \\
\text { Acquisition Supplement }\end{array}$ \\
\hline
\end{tabular}


As shown in Table 2, NAVSUP has 106 acquisition related policy letters resident on the NLL that are applicable and accessible to the NFCS acquisition workforce. Based on review and analysis, the information contained in $28 \%$ of the policy letters listed is obsolete or superseded, and should be removed from the NLL. The remaining $72 \%$ of the policy letters listed are relevant to NAVSUP's mission, and the information contained in them should be incorporated into an acquisition supplement to streamline the process of maintaining and accessing it. 
Table 3. DON SAP Policy Letters (after NLL, 2015)

\begin{tabular}{|c|c|c|c|c|}
\hline $\begin{array}{l}\text { Policy } \\
\text { Letter \# }\end{array}$ & Subject & $\begin{array}{l}\text { Date } \\
\text { Issued }\end{array}$ & $\begin{array}{l}\text { Current? } \\
\text { Y/N }\end{array}$ & Comments \\
\hline $\begin{array}{l}\text { SA12- } \\
\text { 03R1 }\end{array}$ & $\begin{array}{l}\text { NAVSUP ENTERPRISE POLICY FOR } \\
\text { MANAGEMENT OF UNAUTHORIZED } \\
\text { COMMITMENT REPEAT OFFENDERS - } \\
\text { REVISION } 1\end{array}$ & Aug-12 & Y & Relevant \\
\hline SA12-02 & $\begin{array}{l}\text { NAVSUP ENTERPRISE ACQUISITION POLICY } \\
\text { FOR CONTRACTING FOR CONFERENCES }\end{array}$ & Feb-12 & $\mathrm{N}$ & Relevant \\
\hline SA12-01 & $\begin{array}{l}\text { NAVSUP IMPLEMENTATION OF } \\
\text { DEPARTMENT OF NAVY (DON) FURNITURE } \\
\text { ACQUISITION POLICY }\end{array}$ & Oct-11 & $Y$ & Relevant \\
\hline $\begin{array}{l}\text { SA11-02 } \\
\text { (ENCL 2) }\end{array}$ & $\begin{array}{l}\text { NAVSUP ENTERPRISE FURNITURE POLICY } \\
\text { (ENCL 2) }\end{array}$ & Nov-10 & $Y$ & Relevant \\
\hline SA11-02 & $\begin{array}{l}\text { NAVSUP ENTERPRISE FURNITURE POLICY } \\
\text { STANDARD PROCUREMENT SYSTEM (SPS) } \\
\text { ORDERING GUIDANCE }\end{array}$ & Nov-10 & $Y$ & Relevant \\
\hline SA11-01 & $\begin{array}{l}\text { TEMPORARY AUTHORITY TO ISSUE ORDERS } \\
\text { FOR VERIZON WIRELESS SERVICES } \\
\text { OUTSIDE NAVY CONTRACT N00244-05-D- } \\
0012\end{array}$ & Nov-10 & $\mathrm{N}$ & Obsolete \\
\hline SA10-12 & $\begin{array}{l}\text { UPDATED GUIDANCE FOR THE } \\
\text { DEPARTMENT OF THE NAVY ACQUISITION } \\
\text { OF OFFICE SUPPLIES }\end{array}$ & Aug-10 & $Y$ & Relevant \\
\hline SA10-10 & $\begin{array}{l}\text { INTERIM CHANGE TO NAVSUPINSTS } \\
4200.81 E \text { 4200.82D } 4200.85 D\end{array}$ & Aug-10 & Y & Relevant \\
\hline SA10-08 & $\begin{array}{l}\text { PROVISIONS OR CLAUSE USE IN } \\
\text { COMMERCIAL ITEM ACQUISITIONS }\end{array}$ & May-10 & $Y$ & Relevant \\
\hline SA10-06 & $\begin{array}{l}\text { PURCHASE FROM FEDERAL PRISON } \\
\text { INDUSTRIES; UPDATED LIST OF FEDERAL } \\
\text { SUPPLY CLASSIFICATION CODES (FSCS) TO } \\
\text { BE COMPLETED }\end{array}$ & Apr-10 & $\mathrm{N}$ & Superseded \\
\hline SA10-04 & $\begin{array}{l}\text { FEDERAL PROCUREMENT DATA SYSTEM } \\
\text { (FPDS) VERSION 1.4 CERTIFICATION AND } \\
\text { DEPLOYMENT REQUIREMENTS }\end{array}$ & Mar-10 & $\mathrm{N}$ & Obsolete \\
\hline SA10-03 & $\begin{array}{l}\text { NAVY GUIDANCE FOR PURCHASING } \\
\text { JANITORIAL AND SANITATION SUPPLIES }\end{array}$ & Mar-10 & $Y$ & Relevant \\
\hline SA10-02 & $\begin{array}{l}\text { EXTENSION OF AUTHORITY FOR USE OF } \\
\text { SIMPLIFIED ACQUISITION PROCEDURES FOR } \\
\text { CERTAIN COMMERCIAL ITEMS }\end{array}$ & Jan-10 & $\mathrm{N}$ & Superseded \\
\hline SA09-07 & $\begin{array}{l}\text { CLASS DEVIATION TO THE DFARS TO } \\
\text { IMPLEMENT DEPUTY SECRETARY OF } \\
\text { DEFENSE DETERMINATION AND FINDINGS } \\
\text { (D\&FS) REGARDING FOREIGN } \\
\text { PARTICIPATION IN DOD ACQUISITIONS IN } \\
\text { SUPPORT OF OPERATIONS IN AFGHANISTAN }\end{array}$ & Aug-09 & $\mathrm{N}$ & Obsolete \\
\hline SA09-06 & $\begin{array}{l}\text { RANDOLPH SHEPPARD ACT CONTRACT } \\
\text { ACTION REPORTING }\end{array}$ & Aug-09 & $\mathrm{N}$ & Superseded \\
\hline
\end{tabular}


Table 3. DON SAP Policy Letters (after NLL, 2015) (continued)

\begin{tabular}{|c|c|c|c|c|}
\hline $\begin{array}{l}\text { Policy } \\
\text { Letter \# }\end{array}$ & Subject & $\begin{array}{l}\text { Date } \\
\text { Issued }\end{array}$ & $\begin{array}{l}\text { Current? } \\
\text { Y/N }\end{array}$ & Comments \\
\hline SA08-08 & $\begin{array}{l}\text { REQUESTS FOR AUTHORITY TO CONTRACT } \\
\text { WITH GOVERNMENT EMPLOYEES }\end{array}$ & Jul-08 & Y & Relevant \\
\hline SA09-05 & $\begin{array}{l}\text { CLASS DEVIATION - COMMERCIAL ITEM } \\
\text { OMNIBUS CLAUSES FOR ACQUISITIONS USING } \\
\text { STANDARD PROCUREMENT SYSTEM }\end{array}$ & Jul-09 & $\mathrm{N}$ & Obsolete \\
\hline SA09-02 & $\begin{array}{l}\text { REPORTING AWARDS TO THE FEDERAL } \\
\text { PROCUREMENT DATA SYSTEM - NEXT } \\
\text { GENERATION (FPDS-NG) }\end{array}$ & Oct-08 & Y & Relevant \\
\hline SA09-01 & $\begin{array}{l}\text { NAVY OFFICE SUPPLY DOD EMALL SHOPPING: } \\
\text { SHOPPING BY PART NUMBER/MATERIAL } \\
\text { NUMBERS FOR OFFICES SUPPLIES TO REDUCE } \\
\text { INSTANCES OF OVERPAYMENT }\end{array}$ & Nov-08 & $\mathrm{N}$ & Obsolete \\
\hline SA08-14 & $\begin{array}{l}\text { DETERMINATION AND FINDINGS (D\&F) FOR } \\
\text { PARA-ARAMID FIBERS AND YARNS - } \\
\text { QUALIFYING COUNTRIES }\end{array}$ & Aug-08 & $\mathrm{N}$ & Superseded \\
\hline SA08-05 & $\begin{array}{l}\text { REQUIREMENT TO INCLUDE THE NAVSUP } \\
\text { STANDARD CLAUSE FOR INVOICING AND } \\
\text { PAYMENT INSTRUCTIONS IN CONTRACT } \\
\text { ACTIONS WHEN WIDE AREA WORKFLOW IS } \\
\text { THE METHOD OF SUBMISSION }\end{array}$ & Apr-08 & Y & Relevant \\
\hline SA08-03 & $\begin{array}{l}\text { IMPLEMENTING GUIDANCE FOR DEPARTMENT } \\
\text { OF THE NAVY ACQUISITION POLICY ON OFFICE } \\
\text { SUPPLIES (SPIRAL II) }\end{array}$ & Feb-08 & $\mathrm{N}$ & Superseded \\
\hline SA08-02 & SECTION 508 COMPLIANCE & Jan-08 & Y & Relevant \\
\hline $\begin{array}{l}\text { SA08- } \\
01 A\end{array}$ & $\begin{array}{l}\text { POLICIES AND PROCEDURES FOR } \\
\text { WARRANTING CONTRACTING OFFICERS } \\
\text { AWARDING ACTIONS USING SAP (ENCL } 1 \text { IN } \\
\text { WORD) }\end{array}$ & Jan-08 & Y & Relevant \\
\hline SA08-01 & $\begin{array}{l}\text { POLICIES AND PROCEDURES FOR } \\
\text { WARRANTING CONTRACTING OFFICERS } \\
\text { AWARDING ACTIONS USING SIMPLIFIED } \\
\text { ACQUISITION PROCEDURES (SAP) }\end{array}$ & Jan-08 & Y & Relevant \\
\hline SA07-01 & $\begin{array}{l}\text { INTERIM CHANGES TO THE DEPARTMENT OF } \\
\text { NAVY SIMPLIFIED ACQUISITION PROCEDURES } \\
\text { INSTRUCTION }\end{array}$ & Feb-07 & Y & Relevant \\
\hline SA06-10 & SPS CONSOLIDATED SERVER TIME ZONE & Jun-06 & $\mathrm{N}$ & Obsolete/Cancel \\
\hline SA06-08 & ESTABLISHED CATALOG OR MARKET PRICES & Mar-06 & Y & Relevant \\
\hline SA06-07 & $\begin{array}{l}\text { PURCHASE OF COMMERCIAL } \\
\text { TRANSPORTATION FOR DOD PASSENGERS } \\
\text { WITHIN CONUS }\end{array}$ & Mar-06 & Y & Relevant \\
\hline
\end{tabular}


Table 3. DON SAP Policy Letters (after NLL, 2015) (continued)

\begin{tabular}{|c|l|c|c|c|}
\hline $\begin{array}{c}\text { Policy } \\
\text { Letter \# }\end{array}$ & \multicolumn{1}{|c|}{ Subject } & $\begin{array}{c}\text { Date } \\
\text { Issued }\end{array}$ & $\begin{array}{c}\text { Current? } \\
\text { Y/N }\end{array}$ & Comments \\
\hline SA06-06 & $\begin{array}{l}\text { USE OF APPROPRIATED FUNDS TO PURCHASE } \\
\text { FOOD AT CONFERENCES MEETINGS AND } \\
\text { EVENTS }\end{array}$ & Mar-06 & $\mathrm{N}$ & Relevant \\
\hline SA06-05 & $\begin{array}{l}\text { USE OF MILITARY EXCHANGES FOR PHYSICAL } \\
\text { TRAINING GEAR PROCUREMENTS }\end{array}$ & Jan-06 & $\mathrm{Y}$ & Relevant \\
\hline SA06-03 & $\begin{array}{l}\text { PROPOSED ADDITIONS TO THE JAVITS-WAGNER- } \\
\text { O'DAY (JWOD) PROGRAM PROCUREMENT LIST }\end{array}$ & Apr-06 & $\mathrm{Y}$ & Relevant \\
\hline SA06-01 & $\begin{array}{l}\text { INCREASED THRESHOLDS FOR PROCUREMENTS } \\
\text { IN SUPPORT OF HURRICANE KATRINA RESCUE } \\
\text { AND RELIEF EFFORTS }\end{array}$ & Oct-05 & $\mathrm{N}$ & Obsolete \\
\hline SA05-03 & $\begin{array}{l}\text { DON ACQUISITION POLICY ON MOBILE } \\
\text { (CELLULAR) PHONE AND DATA EQUIPMENT AND } \\
\text { SERVICES }\end{array}$ & May-05 & $\mathrm{Y}$ & Relevant \\
\hline SA04-03 & $\begin{array}{l}\text { ACQUISITION POLICY ON FACILITATING VENDOR } \\
\text { SHIPMENTS IN THE DOD ORGANIC DISTRIBUTION } \\
\text { SYSTEM }\end{array}$ & Nov-03 & $\mathrm{N}$ & Relevant \\
\hline SA-SEP-05 & $\begin{array}{l}\text { SONTINGENCY OPERATIONS PROCUREMENT } \\
\text { AUTHORITY APPLIES TO SUPPORT EFFORTS } \\
\text { RELATING TO HURRICANE KATRINA }\end{array}$ & Oct-03 & $\mathrm{N}$ & Obsolete \\
\hline
\end{tabular}

As shown in Table 3, NAVSUP has 36 acquisition related policy letters resident on the NLL that are applicable and accessible to the DON acquisition workforce when using simplified acquisition procedures. Based on review and analysis, the information contained in $38 \%$ of the policy letters listed is obsolete or superseded, and should be removed from the NLL. The remaining $62 \%$ of the policy letters listed are relevant to the Navy's mission, and the information contained in them should be incorporated into NAVSUPINST 4200.85 to streamline the process of maintaining and accessing it in a more timely and efficient manner. 
Table 4. Obsolete/Superseded Policy Letters (after NLL, 2015)

\begin{tabular}{|c|c|c|}
\hline $\begin{array}{l}\text { Policy } \\
\text { Letter \# }\end{array}$ & Subject & Date Issued \\
\hline SA11-01 & $\begin{array}{l}\text { TEMPORARY AUTHORITY TO ISSUE ORDERS FOR VERIZON WIRELESS SERVICES } \\
\text { OUTSIDE NAVY CONTRACT N00244-05-D-0012 }\end{array}$ & Nov-10 \\
\hline SA10-04 & $\begin{array}{l}\text { FEDERAL PROCUREMENT DATA SYSTEM (FPDS) VERSION } 1.4 \text { CERTIFICATION } \\
\text { AND DEPLOYMENT REQUIREMENTS }\end{array}$ & Mar-10 \\
\hline SA09-07 & $\begin{array}{l}\text { CLASS DEVIATION TO THE DFARS TO IMPLEMENT DEPUTY SECRETARY OF } \\
\text { DEFENSE DETERMINATION AND FINDINGS (D\&FS) REGARDING FOREIGN } \\
\text { PARTICIPATION IN DOD ACQUISITIONS IN SUPPORT OF OPERATIONS IN } \\
\text { AFGHANISTAN }\end{array}$ & Aug-09 \\
\hline SA09-05 & $\begin{array}{l}\text { CLASS DEVIATION - COMMERCIAL ITEM OMNIBUS CLAUSES FOR ACQUISITIONS } \\
\text { USING STANDARD PROCUREMENT SYSTEM }\end{array}$ & Jul-09 \\
\hline SA09-01 & $\begin{array}{l}\text { NAVY OFFICE SUPPLY DOD EMALL SHOPPING: SHOPPING BY PART } \\
\text { NUMBER/MATERIAL NUMBERS FOR OFFICES SUPPLIES TO REDUCE INSTANCES } \\
\text { OF OVERPAYMENT }\end{array}$ & Nov-08 \\
\hline SA06-10 & SPS CONSOLIDATED SERVER TIME ZONE & Jun-06 \\
\hline $10-10$ & $\begin{array}{l}\text { FEDERAL PROCUREMENT DATA SYSTEM (FPDS) VERSION } 1.4 \text { CERTIFICATION } \\
\text { AND DEPLOYMENT REQUIREMENTS }\end{array}$ & Mar-10 \\
\hline $10-07$ & $\begin{array}{l}\text { GUIDANCE ON REVIEWING CONTRACTOR REPORTS REQUIRED BY THE AMERICAN } \\
\text { RECOVERY AND REINVESTMENT ACT OF } 2009\end{array}$ & Jan-10 \\
\hline $10-05$ & CLASS DEVIATION -LIMITATIONS ON PASS-THROUGH CHARGES & Jan-10 \\
\hline $10-02$ & RECOVERY ACT INTERIM GUIDANCE ON REVIEWING CONTRACTOR REPORTS & Oct-09 \\
\hline $09-27$ & $\begin{array}{l}\text { CLASS DEVIATION TO THE DFARS TO IMPLEMENT DEPUTY SECRETARY OF } \\
\text { DEFENSE DETERMINATION AND FINDINGS (D\&FS) REGARDING FOREIGN } \\
\text { PARTICIPATION IN DOD ACQUISITIONS IN SUPPORT OF OPERATIONS IN } \\
\text { AFGHANISTAN }\end{array}$ & Aug-09 \\
\hline $09-21$ & $\begin{array}{l}\text { CLASS DEVIATION - COMMERCIAL ITEM OMNIBUS CLAUSES FOR ACQUISITIONS } \\
\text { USING STANDARD PROCUREMENT SYSTEM }\end{array}$ & Jul-09 \\
\hline $06-22$ & SPS CONSOLIDATED SERVER TIME ZONE & Jun-06 \\
\hline $05-18$ & $\begin{array}{l}\text { INCREASED MICRO-PURCHASE THRESHOLD IN SUPPORT OF HURRICANE } \\
\text { KATRINA RESCUE AND RELIEF OPERATIONS }\end{array}$ & Sep-05 \\
\hline $05-11$ & $\begin{array}{l}\text { TEST PROGRAM FOR STREAMLINED CONTRACT CLOSE-OUT PROCEDURES FOR } \\
\text { FIRM-FIXED ORDERS AGAINST GSA FEDERAL SUPPLY SCHEDULE AND INDEFINITE } \\
\text { DELIVERY TYPE CONTRACTS }\end{array}$ & Apr-05 \\
\hline $05-02$ & SMALL BUSINESS TRAINING & Feb-05 \\
\hline $02-20$ & CLASS DEVIATION - INTEREST COSTS & May-02 \\
\hline $02-01$ & $\begin{array}{l}\text { AUTHORIZATION TO UTILIZE CONTINGENCY OPERATIONS CONTRACTING } \\
\text { PROCEDURES }\end{array}$ & Oct-01 \\
\hline $14-001$ & $\begin{array}{l}\text { NAVSUP FY14 CONTRACTUAL PLANNING FOR AGENCY OPERATIONS DURING } \\
\text { GOVERNMENT SHUTDOWN }\end{array}$ & Oct-13 \\
\hline SA06-01 & $\begin{array}{l}\text { INCREASED THRESHOLDS FOR PROCUREMENTS IN SUPPORT OF HURRICANE } \\
\text { KATRINA RESCUE AND RELIEF EFFORTS }\end{array}$ & Oct-05 \\
\hline
\end{tabular}


Table 4. Obsolete/Superseded Policy Letters (after NLL, 2015) (continued)

\begin{tabular}{|c|c|c|}
\hline $\begin{array}{l}\text { Policy } \\
\text { Letter \# }\end{array}$ & Subject & Date Issued \\
\hline $13-002$ & $\begin{array}{l}\text { NAVAL SUPPLY SYSTEMS COMMAND ENTERPRISE ACQUISITION POLICY FOR USE } \\
\text { OF THE GLOBAL BUSINESS SOLUTIONS CONTRACT FOR GENERAL SUPPORT } \\
\text { SERVICES }\end{array}$ & Nov-12 \\
\hline SA10-06 & $\begin{array}{l}\text { PURCHASE FROM FEDERAL PRISON INDUSTRIES; UPDATED LIST OF FEDERAL } \\
\text { SUPPLY CLASSIFICATION CODES (FSCS) TO BE COMPLETED }\end{array}$ & Apr-10 \\
\hline SA10-02 & $\begin{array}{l}\text { EXTENSION OF AUTHORITY FOR USE OF SIMPLIFIED ACQUISITION PROCEDURES } \\
\text { FOR CERTAIN COMMERCIAL ITEMS }\end{array}$ & Jan-10 \\
\hline SA09-06 & RANDOLPH SHEPPARD ACT CONTRACT ACTION REPORTING & Aug-09 \\
\hline SA08-14 & $\begin{array}{l}\text { DETERMINATION AND FINDINGS (D\&F) FOR PARA-ARAMID FIBERS AND YARNS - } \\
\text { QUALIFYING COUNTRIES }\end{array}$ & Aug-08 \\
\hline SA08-03 & $\begin{array}{l}\text { IMPLEMENTING GUIDANCE FOR DEPARTMENT OF THE NAVY ACQUISITION POLICY } \\
\text { ON OFFICE SUPPLIES (SPIRAL II) }\end{array}$ & Feb-08 \\
\hline SA03-19 & STREAMLINED CONTRACT CLOSEOUT PROCEDURES & Oct-03 \\
\hline $11-01$ & QUALITY ASSURANCE SELF-ASSESSMENT (QASA) PROGRAM & Dec-10 \\
\hline $10-25$ & $\begin{array}{l}\text { CLASS DEVIATION AWARD FEE REDUCTION OR DENIAL FOR JEOPARDIZING THE } \\
\text { HEALTH OR SAFETY OF GOVERNMENT FOR PERSONNEL }\end{array}$ & Aug-10 \\
\hline $09-23$ & $\begin{array}{l}\text { INTERIM CHANGE TO NAVSUPINST 4200.84H (NEW PROCESS FOR MEDIA } \\
\text { ANNOUNCEMENTS) }\end{array}$ & Jul-09 \\
\hline $09-18$ & $\begin{array}{l}\text { INTERIM CHANGE TO NAVSUP INSTRUCTION 4200.83G CONTRACTING AND } \\
\text { BUSINESS CLEARANCE PROCEDURES AND APPROVALS }\end{array}$ & Oct-09 \\
\hline 09-09 & APPOINTMENT OF COMPETITION ADVOCATES & Dec-08 \\
\hline $08-48$ & $\begin{array}{l}\text { DETERMINATION AND FINDINGS (D\&F) FOR PARA-ARAMID FIBERS AND YARNS - } \\
\text { QUALIFYING COUNTRIES }\end{array}$ & Aug-08 \\
\hline $08-47$ & $\begin{array}{l}\text { CLASS DEVIATION FROM DFARS 237.102-71 LIMITATION ON SERVICE CONTRACTS } \\
\text { FOR MILITARY FLIGHT SIMULATORS }\end{array}$ & Aug-08 \\
\hline $08-24$ & $\begin{array}{l}\text { REQUIREMENT TO INCLUDE THE NAVSUP STANDARD CLAUSE FOR INVOICING } \\
\text { AND PAYMENT INSTRUCTIONS IN CONTRACT ACTIONS WHEN WIDE AREA } \\
\text { WORKFLOW IS THE METHOD OF SUBMISSION }\end{array}$ & Apr-08 \\
\hline $08-18$ & $\begin{array}{l}\text { IMPLEMENTING GUIDANCE FOR DEPARTMENT OF THE NAVY ACQUISITION POLICY } \\
\text { ON OFFICE SUPPLIES (SPIRAL II) }\end{array}$ & Feb-08 \\
\hline 08-16R1 & IMPROVING COMMUNICATIONS DURING COMPETITIVE SOURCE SELECTIONS & Apr -08 \\
\hline $06-26$ & $\begin{array}{l}\text { INTERIM CHANGES TO THE NAVSUP CONTRACTING OFFICER'S REPRESENTATIVE } \\
\text { (COR) INSTRUCTION }\end{array}$ & \\
\hline 06-02C & $\begin{array}{l}\text { POLICY TO ESTABLISH AND IMPLEMENT SELF-ASSESSMENT PLANS ACROSS THE } \\
\text { NAVY FIELD CONTRACTING SYSTEM (NFCS)(ENCL } 3 \text { IN WORD) }\end{array}$ & Jul-06 \\
\hline 06-02B & $\begin{array}{l}\text { POLICY TO ESTABLISH AND IMPLEMENT SELF-ASSESSMENT PLANS ACROSS THE } \\
\text { NAVY FIELD CONTRACTING SYSTEM (NFCS)(ENCL } 2 \text { IN WORD) }\end{array}$ & Jul-06 \\
\hline $06-02 \mathrm{~A}$ & $\begin{array}{l}\text { POLICY TO ESTABLISH AND IMPLEMENT SELF-ASSESSMENT PLANS ACROSS THE } \\
\text { NAVY FIELD CONTRACTING SYSTEM (NFCS)(ENCL } 1 \text { IN WORD) }\end{array}$ & Jul-06 \\
\hline $06-02$ & $\begin{array}{l}\text { POLICY TO ESTABLISH AND IMPLEMENT SELF-ASSESSMENT PLANS ACROSS THE } \\
\text { NAVY FIELD CONTRACTING SYSTEM (NFCS) }\end{array}$ & Jul-06 \\
\hline 05-01 & SMALL BUSINESS TRAINING & Nov-04 \\
\hline
\end{tabular}


Table 4. Obsolete/Superseded Policy Letters (after NLL, 2015) (continued)

\begin{tabular}{|c|l|l|}
\hline $\begin{array}{c}\text { Policy } \\
\text { Letter } \#\end{array}$ & \multicolumn{1}{|c|}{ Subject } & Date Issued \\
\hline SA06-01 & $\begin{array}{l}\text { INCREASED THRESHOLDS FOR PROCUREMENTS IN SUPPORT OF HURRICANE } \\
\text { KATRINA RESCUE AND RELIEF EFFORTS }\end{array}$ & Oct-05 \\
\hline $\begin{array}{c}\text { 1-SEP-05 } \\
\text { SAP }\end{array}$ & $\begin{array}{l}\text { CONTINGENCY OPERATIONS PROCUREMENT AUTHORITY APPLIES TO SUPPORT } \\
\text { EFFORTS RELATING TO HURRICANE KATRINA }\end{array}$ & Oct-03 \\
\hline
\end{tabular}

Based on review and analysis, 45 (32\%) of NAVSUP's policy letters issued between 2002 and 2015, identified in Table 4, are currently obsolete or superseded. These policy letters should be rescinded or cancelled, and removed from the NLL. 
Table 5. Relevant NAVSUP Policy Letters (after NLL, 2015)

\begin{tabular}{|c|c|c|c|}
\hline $\begin{array}{l}\text { Policy } \\
\text { Letter \# }\end{array}$ & Subject & $\begin{array}{l}\text { Date } \\
\text { Issued }\end{array}$ & $\begin{array}{l}\text { Current? } \\
\text { Y/N }\end{array}$ \\
\hline SA12-02 & $\begin{array}{l}\text { NAVSUP ENTERPRISE ACQUISITION POLICY FOR CONTRACTING FOR } \\
\text { CONFERENCES }\end{array}$ & Feb-12 & $\mathrm{N}$ \\
\hline SA12-01 & $\begin{array}{l}\text { NAVSUP IMPLEMENTATION OF DEPARTMENT OF NAVY (DON) } \\
\text { FURNITURE ACQUISITION POLICY }\end{array}$ & Oct-11 & Y \\
\hline $\begin{array}{l}\text { SA11-02 } \\
\text { (ENCL 2) }\end{array}$ & NAVSUP ENTERPRISE FURNITURE POLICY (ENCL 2) & Nov-10 & Y \\
\hline SA11-02 & $\begin{array}{l}\text { NAVSUP ENTERPRISE FURNITURE POLICY STANDARD } \\
\text { PROCUREMENT SYSTEM (SPS) ORDERING GUIDANCE }\end{array}$ & Nov-10 & Y \\
\hline SA10-12 & $\begin{array}{l}\text { UPDATED GUIDANCE FOR THE DEPARTMENT OF THE NAVY } \\
\text { ACQUISITION OF OFFICE SUPPLIES }\end{array}$ & Aug-10 & Y \\
\hline SA10-10 & INTERIM CHANGE TO NAVSUPINSTS 4200.81E 4200.82D 4200.85D & Aug-10 & Y \\
\hline SA10-08 & PROVISIONS OR CLAUSE USE IN COMMERCIAL ITEM ACQUISITIONS & May-10 & Y \\
\hline SA10-03 & $\begin{array}{l}\text { NAVY GUIDANCE FOR PURCHASING JANITORIAL AND SANITATION } \\
\text { SUPPLIES }\end{array}$ & Mar-10 & Y \\
\hline SA09-02 & $\begin{array}{l}\text { REPORTING AWARDS TO THE FEDERAL PROCUREMENT DATA } \\
\text { SYSTEM - NEXT GENERATION (FPDS-NG) }\end{array}$ & Oct-08 & Y \\
\hline SA08-08 & $\begin{array}{l}\text { REQUESTS FOR AUTHORITY TO CONTRACT WITH GOVERNMENT } \\
\text { EMPLOYEES }\end{array}$ & Jul-08 & Y \\
\hline SA08-05 & $\begin{array}{l}\text { REQUIREMENT TO INCLUDE THE NAVSUP STANDARD CLAUSE FOR } \\
\text { INVOICING AND PAYMENT INSTRUCTIONS IN CONTRACT ACTIONS } \\
\text { WHEN WIDE AREA WORKFLOW IS THE METHOD OF SUBMISSION }\end{array}$ & Apr-08 & Y \\
\hline SA08-02 & SECTION 508 COMPLIANCE & Jan-08 & $\mathrm{Y}$ \\
\hline SA08-01A & $\begin{array}{l}\text { POLICIES AND PROCEDURES FOR WARRANTING CONTRACTING } \\
\text { OFFICERS AWARDING ACTIONS USING SAP (ENCL } 1 \text { IN WORD) }\end{array}$ & Jan-08 & Y \\
\hline SA08-01 & $\begin{array}{l}\text { POLICIES AND PROCEDURES FOR WARRANTING CONTRACTING } \\
\text { OFFICERS AWARDING ACTIONS USING SIMPLIFIED ACQUISITION } \\
\text { PROCEDURES (SAP) }\end{array}$ & Jan-08 & Y \\
\hline SA07-01 & $\begin{array}{l}\text { INTERIM CHANGES TO THE DEPARTMENT OF NAVY SIMPLIFIED } \\
\text { ACQUISITION PROCEDURES INSTRUCTION }\end{array}$ & Feb-07 & Y \\
\hline SA06-08 & ESTABLISHED CATALOG OR MARKET PRICES & Mar-06 & Y \\
\hline SA06-07 & $\begin{array}{l}\text { PURCHASE OF COMMERCIAL TRANSPORTATION FOR DOD } \\
\text { PASSENGERS WITHIN CONUS }\end{array}$ & Mar-06 & Y \\
\hline SA06-06 & $\begin{array}{l}\text { USE OF APPROPRIATED FUNDS TO PURCHASE FOOD AT } \\
\text { CONFERENCES MEETINGS AND EVENTS }\end{array}$ & Mar-06 & $\mathrm{N}$ \\
\hline SA06-05 & $\begin{array}{l}\text { USE OF MILITARY EXCHANGES FOR PHYSICAL TRAINING GEAR } \\
\text { PROCUREMENTS }\end{array}$ & Jan-06 & Y \\
\hline SA06-03 & $\begin{array}{l}\text { PROPOSED ADDITIONS TO THE JAVITS-WAGNER-O'DAY (JWOD) } \\
\text { PROGRAM PROCUREMENT LIST }\end{array}$ & Apr-06 & Y \\
\hline SA05-03 & $\begin{array}{l}\text { DON ACQUISITION POLICY ON MOBILE (CELLULAR) PHONE AND DATA } \\
\text { EQUIPMENT AND SERVICES }\end{array}$ & May-05 & Y \\
\hline SA04-03 & $\begin{array}{l}\text { ACQUISITION POLICY ON FACILITATING VENDOR SHIPMENTS IN THE } \\
\text { DOD ORGANIC DISTRIBUTION SYSTEM }\end{array}$ & Nov-03 & $\mathrm{N}$ \\
\hline $11-08$ & $\begin{array}{l}\text { SELF-ASSESSMENT PLANS ACROSS THE NAVY FIELD CONTRACTING } \\
\text { SYSTEM (NFCS) }\end{array}$ & Apr-11 & Y \\
\hline $\begin{array}{c}11-04 \\
(E N C L 2)\end{array}$ & $\begin{array}{l}\text { NAVSUP ENTERPRISE FURNITURE POLICY STANDARD } \\
\text { PROCUREMENT SYSTEM ORDERING GUIDANCE (ENCL } 2 \text { ) }\end{array}$ & Nov-10 & Y \\
\hline
\end{tabular}


Table 5. Relevant NAVSUP Policy Letters (after NLL, 2015) (continued)

\begin{tabular}{|c|c|c|c|}
\hline $\begin{array}{l}\text { Policy } \\
\text { Letter \# }\end{array}$ & Subject & $\begin{array}{l}\text { Date } \\
\text { Issued }\end{array}$ & Current? Y/N \\
\hline $11-04$ & $\begin{array}{l}\text { NAVSUP ENTERPRISE FURNITURE POLICY STANDARD } \\
\text { PROCUREMENT SYSTEM (SPS) ORDERING GUIDANCE }\end{array}$ & Nov-10 & $\mathrm{Y}$ \\
\hline $11-03$ & $\begin{array}{l}\text { TRAINING PLAN FOR NON-DIRECTOR (ACQUISITION CAREER } \\
\text { MANAGEMENT (NON-DACM) CONTRACTING INTERNS/CAREER } \\
\text { LADDER EMPLOYEES }\end{array}$ & Dec-10 & $\mathrm{N}$ \\
\hline $10-23$ & $\begin{array}{l}\text { UPDATED GUIDANCE FOR THE DEPARTMENT OF THE NAVY } \\
\text { ACQUISITION OF OFFICE SUPPLIES }\end{array}$ & Aug-10 & $\mathrm{Y}$ \\
\hline $10-18$ & PROVISIONS OR CLAUSE USE IN COMMERCIAL ITEM ACQUISITIONS & May-10 & $\mathrm{Y}$ \\
\hline $10-17$ & RESOLVING CONTRACT AUDIT RECOMMENDATIONS & Jun-10 & $\mathrm{Y}$ \\
\hline $10-13$ & $\begin{array}{l}\text { DEPARTMENT OF THE NAVY (DON) PROCESS FOR COLLECTING } \\
\text { EVALUATING AND REPORTING AWARD AND INCENTIVE FEES } \\
\text { EARNED }\end{array}$ & Apr-10 & $\mathrm{Y}$ \\
\hline $10-12$ & CONTINUATION OF ESSENTIAL CONTRACTOR SERVICES & Mar-10 & Y \\
\hline $10-09$ & $\begin{array}{l}\text { CLASS DEVIATION TO IMPLEMENT ADDITIONAL CONTRACTOR } \\
\text { REQUIREMENTS AND RESPONSIBILITIES RESTRICTING THE USE OF } \\
\text { MANDATORY ARBITRATION AGREEMENTS }\end{array}$ & Feb-10 & $\mathrm{Y}$ \\
\hline $10-06$ & $\begin{array}{l}\text { NAVY GUIDANCE FOR PURCHASING JANITORIAL AND SANITATION } \\
\text { SUPPLIES }\end{array}$ & Mar-10 & $\mathrm{Y}$ \\
\hline $10-01$ & $\begin{array}{l}\text { MANAGEMENT OF NAVY CONTRACTS ON DOD EMALL NAVY } \\
\text { CORRIDOR }\end{array}$ & Nov-09 & Y \\
\hline $09-28$ & SEAPORT ENHANCED PROGRAM & Aug-09 & Y \\
\hline $09-19$ & $\begin{array}{l}\text { GOVERNMENT SOURCE APPROVAL REQUIRED PRIOR TO AWARD } \\
\text { (JUN 2009) (NAVSUP) }\end{array}$ & Jun-09 & Y \\
\hline $09-15$ & PROPER USE OF TIME AND MATERIAL CONTRACT TYPES & May-09 & $\mathrm{Y}$ \\
\hline $09-13$ & $\begin{array}{l}\text { PAST PERFORMANCE INFORMATION RETRIEVAL SYSTEM - } \\
\text { STATISTICAL REPORTING (PPIRS-SR) }\end{array}$ & Mar-09 & Y \\
\hline $09-10$ & $\begin{array}{l}\text { IMPLEMENTATION OF ELECTRONIC SUBCONTRACTING REPORTING } \\
\text { SYSTEM (ESRS) AND REPORTING FUNCTIONS }\end{array}$ & Jan-09 & $\mathrm{Y}$ \\
\hline $09-05$ & $\begin{array}{l}\text { REPORTING PROFIT AND FEE STATISTICS USING WEB-BASED } \\
\text { APPLICATION }\end{array}$ & Feb-09 & $\mathrm{Y}$ \\
\hline $09-03$ & $\begin{array}{l}\text { SPECIAL LIMITATIONS ON USE OF OTHER THAN FIXED PRICE } \\
\text { CONTRACTS FOR FOLLOW-ON AND RENEWAL CONTRACTS }\end{array}$ & Feb-09 & Y \\
\hline 09-01 & $\begin{array}{l}\text { REPORTING AWARDS TO THE FEDERAL PROCUREMENT DATA } \\
\text { SYSTEM - NEXT GENERATION (FPDS-NG) }\end{array}$ & Oct-08 & $\mathrm{Y}$ \\
\hline 08-31 & $\begin{array}{l}\text { REQUESTS FOR AUTHORITY TO CONTRACT WITH GOVERNMENT } \\
\text { EMPLOYEES }\end{array}$ & Jul-08 & $\mathrm{Y}$ \\
\hline $08-28$ & POLICY FOR USE OF SHARED SOURCES & Jun-08 & $\mathrm{Y}$ \\
\hline $08-25$ & $\begin{array}{l}\text { INTERAGENCY ACQUISITION WITH DEPARTMENT OF THE } \\
\text { INTERIOR/ACQUISITION SERVICES DIRECTORATE }\end{array}$ & May-08 & $\mathrm{N}$ \\
\hline $08-20$ & $\begin{array}{l}\text { AUTHORITY TO ESTABLISH TRANSPORTATION SERVICES } \\
\text { CONTRACTS }\end{array}$ & Feb-08 & $\mathrm{Y}$ \\
\hline
\end{tabular}


Table 5. Relevant NAVSUP Policy Letters (after NLL, 2015) (continued)

\begin{tabular}{|c|c|c|c|}
\hline $\begin{array}{l}\text { Policy } \\
\text { Letter \# }\end{array}$ & Subject & $\begin{array}{l}\text { Date } \\
\text { Issued }\end{array}$ & Current? Y/N \\
\hline $08-17$ & SECTION 508 COMPLIANCE & Jan-08 & Y \\
\hline $08-15$ & BODY ARMOR APPROVED FOR NAVY PURCHASE & Jan-08 & $\mathrm{N}$ \\
\hline $08-07$ & $\begin{array}{l}\text { ACCESS TO INFORMATION OTHER THAN COST AND PRICING DATA } \\
\text { WITH EXCLUSIVE DISTRIBUTORS/DEALERS }\end{array}$ & Nov-07 & $\mathrm{Y}$ \\
\hline $07-27$ & $\begin{array}{l}\text { APPLICABILITY OF THE JAVITS-WAGNER-O'DAY ACT AND THE } \\
\text { RANDOLPH-SHEPPARD ACT TO MILITARY DINING FACILITY } \\
\text { CONTRACTS }\end{array}$ & Apr-07 & Y \\
\hline $07-20$ & CONTRACTING POSTAL FUNCTIONS POLICY MEMORANDUM & Apr-07 & $\mathrm{Y}$ \\
\hline $06-25$ & $\begin{array}{l}\text { SPECIAL REVIEW REQUIREMENTS FOR OFFICE SUPPLY CONTRACTS } \\
\text { AND OPTIONS }\end{array}$ & Aug-06 & Y \\
\hline $06-17$ & AWARD FEE CONTRACTS & May-06 & $\mathrm{N}$ \\
\hline $06-16$ & $\begin{array}{l}\text { PURCHASE OF COMMERCIAL TRANSPORTATION FOR DOD } \\
\text { PASSENGERS WITHIN CONUS }\end{array}$ & Mar-06 & $\mathrm{N}$ \\
\hline $06-15$ & $\begin{array}{l}\text { USE OF APPROPRIATED FUNDS TO PURCHASE FOOD AT } \\
\text { CONFERENCES MEETINGS AND EVENTS }\end{array}$ & Mar-06 & $\mathrm{N}$ \\
\hline $06-12$ & $\begin{array}{l}\text { PROPOSED ADDITIONS TO THE JAVITS-WAGNER-O'DAY (JWOD) } \\
\text { PROGRAM PROCUREMENT LIST }\end{array}$ & Apr-06 & $\mathrm{N}$ \\
\hline $06-11$ & $\begin{array}{l}\text { USE OF MILITARY EXCHANGES FOR PHYSICAL TRAINING GEAR } \\
\text { PROCUREMENTS }\end{array}$ & Jan-06 & Y \\
\hline $06-06$ & APPOINTMENT OF SOURCE SELECTION AUTHORITIES & Jan-06 & Y \\
\hline $05-17 A$ & SEAPORT-E (WAIVER IN WORD) & Aug-05 & Y \\
\hline $05-17$ & SEAPORT-E IMPLEMENTATION POLICY & Aug-05 & Y \\
\hline $05-10$ & $\begin{array}{l}\text { DON ACQUISITION POLICY ON MOBILE (CELLULAR) PHONE AND DATA } \\
\text { EQUIPMENT AND SERVICES }\end{array}$ & May-05 & Y \\
\hline $15-002$ & $\begin{array}{l}\text { NAVAL SUPPLY SYSTEMS COMMAND ENTERPRISE MANDATORY USE } \\
\text { OF REVERSE AUCTIONS }\end{array}$ & Nov-14 & Y \\
\hline $14-065$ & TEST PROGRAM FOR STREAMLINED CONTRACT CLOSE-OUT & Apr-14 & Y \\
\hline $14-010$ & USE OF TECHNICAL DIRECTION LETTERS & Sep-14 & Y \\
\hline $14-009$ & AFLOAT AUTHORITY & Nov-14 & Y \\
\hline 14-008 & $\begin{array}{l}\text { REDUCING RELIANCE ON BRIDGE CONTRACTING ACTIONS BY } \\
\text { LEVERAGING USE OF ESTABLISHED CONTRACTS VEHICLES }\end{array}$ & Jul-14 & Y \\
\hline 14-005 & APPOINTMENT OF COMPETITION ADVOCATES & Mar-14 & Y \\
\hline $14-004$ & $\begin{array}{l}\text { SPECIFYING SECURITY REQUIREMENTS - USE OF FEDERAL } \\
\text { ACQUISITION REGULATION CLAUSE 52.204-2 }\end{array}$ & Feb-14 & Y \\
\hline
\end{tabular}


Table 5. Relevant NAVSUP Policy Letters (after NLL, 2015) (continued)

\begin{tabular}{|c|c|c|c|}
\hline $\begin{array}{l}\text { Policy } \\
\text { Letter \# }\end{array}$ & Subject & $\begin{array}{l}\text { Date } \\
\text { Issued }\end{array}$ & Current? Y/N \\
\hline $14-003$ & $\begin{array}{l}\text { TERMINATION FOR DEFAULT OR CAUSE REPORTING IN THE } \\
\text { FEDERAL AWARDEE PERFORMANCE AND INTEGRITY INFORMATION } \\
\text { SYSTEM }\end{array}$ & Oct-13 & $\mathrm{Y}$ \\
\hline $13-010$ & QUALITY ASSURANCE SELF-ASSESSMENT (QASA) PROGRAM & Sep-13 & $\mathrm{Y}$ \\
\hline $13-009$ & $\begin{array}{l}\text { SELF ASSESSMENT PLANS ACROSS THE NAVY FIELD CONTRACTING } \\
\text { SYSTEM }\end{array}$ & Aug-13 & $\mathrm{Y}$ \\
\hline $13-008$ & $\begin{array}{l}\text { PROCEDURES FOR ACQUIRING CONTRACT LINGUIST FOREIGN } \\
\text { LANGUAGE SUPPORT }\end{array}$ & Aug-13 & $\mathrm{Y}$ \\
\hline $13-007$ & $\begin{array}{l}\text { CONTRACTOR UNCLASSIFIED ACCESS TO FEDERALLY CONTROLLED } \\
\text { FACILITIES, SENSITIVE INFORMATION, INFORMATION TECHNOLOGY } \\
\text { SYSTEMS OR PROTECTED HEALTH INFORMATION }\end{array}$ & Sep-13 & $\mathrm{Y}$ \\
\hline $13-006$ & $\begin{array}{l}\text { DELEGATION OF AUTHORITY RELATING TO LIMITATION ON AMOUNTS } \\
\text { AVAILABLE FOR CONTRACT SERVICES }\end{array}$ & Mar-13 & $\mathrm{Y}$ \\
\hline $13-004$ & EQUIPMENT LEASE OR PURCHASE & Jun-13 & $\mathrm{Y}$ \\
\hline 13-003 & MAINTENANCE REPAIR OPERATION SUPPLIES & Apr-13 & $\mathrm{Y}$ \\
\hline $12-17$ & $\begin{array}{l}\text { INFORMATION TECHNOLOGY PROCUREMENT APPROVAL AND } \\
\text { OVERSIGHT AUTHORITY }\end{array}$ & Oct-12 & $Y$ \\
\hline $12-15$ & $\begin{array}{l}\text { NAVSUP ENTERPRISE SERVICE ACQUISITION REQUIREMENTS } \\
\text { OVERSIGHT POLICY }\end{array}$ & Oct-12 & $Y$ \\
\hline $12-14$ & $\begin{array}{l}\text { NAVSUP ENTERPRISE CONTRACTING POLICY FOR INCREASING } \\
\text { SMALL BUSINESS OPPORTUNITIES IN SERVICE ACQUISITIONS }\end{array}$ & Jul-12 & $Y$ \\
\hline $12-12$ & $\begin{array}{l}\text { INTERIM CHANGE TO NAVSUP INSTRUCTION } 4200.83 \mathrm{H} \text { CONTRACTING } \\
\text { AND BUSINESS CLEARANCE PROCEDURES AND APPROVALS }\end{array}$ & Jun-12 & $\mathrm{Y}$ \\
\hline 12-09R1 & $\begin{array}{l}\text { NAVSUP ENTERPRISE POLICY FOR MANAGEMENT OF } \\
\text { UNAUTHORIZED COMMITMENT REPEAT OFFENDERS - REVISION } 1\end{array}$ & Aug-12 & $Y$ \\
\hline $12-09$ & $\begin{array}{l}\text { NAVSUP ENTERPRISE CONTRACTING POLICY FOR MANAGEMENT OF } \\
\text { UNAUTHORIZED COMMITMENT REPEAT OFFENDERS }\end{array}$ & Jun-12 & $Y$ \\
\hline $12-08$ & $\begin{array}{l}\text { NAVSUP ENTERPRISE ACQUISITION POLICY FOR CONTRACTING FOR } \\
\text { CONFERENCES }\end{array}$ & Feb-12 & $\mathrm{N}$ \\
\hline $12-02$ & $\begin{array}{l}\text { NAVSUP IMPLEMENTATION OF DEPARTMENT OF NAVY (DON) } \\
\text { FURNITURE ACQUISITION POLICY }\end{array}$ & Oct-11 & $Y$ \\
\hline
\end{tabular}


Table 5. Relevant NAVSUP Policy Letters (after NLL, 2015) (continued)

\begin{tabular}{|c|c|c|}
\hline $\begin{array}{l}\text { Policy } \\
\text { Letter \# }\end{array}$ & Subject & Date Issued \\
\hline $12-13$ & $\begin{array}{l}\text { TEST PROGRAM FOR STREAMLINED CONTRACT CLOSE-OUT PROCEDURES FOR } \\
\text { FIRMFIXED ORDERS AGAINST GSA FEDERAL SUPPLY SCHEDULE AND INDEFINITE } \\
\text { DELIVERY TYPE CONTRACTS }\end{array}$ & May-12 \\
\hline $08-12$ & CONTRACTING COMMUNITY MANAGEMENT PLAN & Jan-08 \\
\hline 08-09 & $\begin{array}{l}\text { IMPLEMENTATION OF SYNCHRONIZED PREDEPLOYMENT AND OPERATIONAL } \\
\text { TRACKER (SPOT) }\end{array}$ & Nov-07 \\
\hline 08-02 & $\begin{array}{l}\text { CONTENT OF DETERMINATIONS AND FINDINGS (D\&F) TO PROCEED IN THE FACE } \\
\text { OF PROTESTS TO THE GENERAL ACCOUNTING OFFICE }\end{array}$ & Oct-07 \\
\hline $07-17$ & $\begin{array}{l}\text { ASSIGNMENT OF PROPER PROCUREMENT INSTRUMENT IDENTIFICATION } \\
\text { NUMBERS (PIINS) FOR MASTER AGREEMENTS FOR THE REPAIR AND ALTERATION } \\
\text { OF VESSELS (MARAVS) AGREEMENT }\end{array}$ & Feb-07 \\
\hline $07-14$ & SOFTWARE PROCESS IMPROVEMENT INITIATIVE CONTRACT LANGUAGE & Feb-07 \\
\hline 07-06 & $\begin{array}{l}\text { ANTI-TERRORISM/FORCE PROTECTION MEASURES FOR PROCUREMENTS } \\
\text { SUPPORTING U.S. NAVY PORT VISITS }\end{array}$ & Mar-07 \\
\hline 07-03A & BASE SUPPLY CENTER STATEMENT OF WORK (ENCL 1 IN WORD) & Nov-06 \\
\hline $07-03$ & BASE SUPPLY CENTER STATEMENT OF WORK & Nov-06 \\
\hline 07-02 & $\begin{array}{l}\text { REVIEW AND DOCUMENTATION OF PERFORMANCE BASED LOGISTICS (PBL) } \\
\text { CONTRACTS }\end{array}$ & Oct-06 \\
\hline 07-01 & NAVSUP/NAVFAC CONTRACTING RESPONSIBILITIES & Oct-06 \\
\hline $04-14$ & NAVSUP NON-NAVY OWNED CRANES NON-STANDARD CLAUSE & Sep-04 \\
\hline 04-03 & $\begin{array}{l}\text { ACQUISITION POLICY ON FACILITATING VENDOR SHIPMENTS IN THE DOD } \\
\text { ORGANIC DISTRIBUTION SYSTEM }\end{array}$ & Nov-03 \\
\hline
\end{tabular}

Based on review and analysis, $68 \%$ of NAVSUP's policy letters issued between 2002 and 2015, identified in Table 5, are relevant to NAVSUP and the Navy's mission. The information contained in these policy letters should be incorporated into an acquisition supplement or the appropriate instruction, as applicable, once they have been reviewed by NAVSUP Contracting Directorate SMEs for accuracy. 


\section{NAVSUP PUBLICATIONS}

Table 6 lists NAVSUP acquisition related publications. The data contained in these publications were reviewed for relevancy. The results of this data analysis are not all inclusive of revisions needed for these publications. A more thorough review of each publication, for accuracy and relevancy, should be completed by NAVSUP Contracting Directorate SMEs.

Table 6. NAVSUP Publications (after NLL, 2015)

\begin{tabular}{|l|l|l|l|l|}
\hline Publication & \multicolumn{1}{|c|}{ Title } & $\begin{array}{l}\text { Date Issued/ } \\
\text { Updated }\end{array}$ & \multicolumn{1}{|c|}{ Current? } & Comments \\
\hline 547 & $\begin{array}{l}\text { Contract Request } \\
\text { Preparation Guide }\end{array}$ & 2003 & N & Relevant \\
\hline 592 & NAVSUP Clause Book & 2011 & N & Relevant \\
\hline 736 & $\begin{array}{l}\text { NAVSUP Contract Closeout } \\
\text { Guidebook }\end{array}$ & 2011 & N & Relevant \\
\hline 738 & Ordering Officer Guidebook & 2007 & N & Relevant \\
\hline
\end{tabular}

(1) NAVSUP Publication 547

NAVSUP Publication 547, Contract Request Preparation Guide, was published to provide Navy activities with information to assist in the preparation and submission of Navy Comptroller Form 2276 (NAVCOMPT 2276), Request for Contractual Procurement (RCP). "A NAVCOMPT Form 2276 is a purchase request (or requisition) document that establishes the following:

- $\quad$ Request has been approved by the requiring activity or his or her designee

- $\quad$ Funds have been certified through the appropriate budget office

- $\quad$ Purchase request has a fund cite

- $\quad$ Purchase request has sufficient funds to cover purchase" (Defense Acquisition University, n.d.).

This RCP guide is intended to provide those who prepare RCPs with a clear understanding of the specific information required for acquisitions and save both technical and contracting offices time and reduce administrative burden. It sets forth a standard format for the submission of this information. 
This publication was last updated in May 2003. It is outdated as a result of implementation of Enterprise Resource Planning (ERP) and should be updated. The information contained in this publication is relevant to NAVSUP's mission and should be incorporated into a NAVSUP acquisition supplement once it has been updated to reflect the most current information and guidance pertaining to RCPs.

\section{(2) NAVSUP Publication 592}

NAVSUP Publication 592, Clause Book, is published to provide NFCS activities with a consolidated listing of approved Component solicitation provisions and contract clauses and to explain the procedures governing clause usage. This publication contains the only provisions and clauses authorized to be used in solicitations and contracts issued by NFCS activities in addition to FAR, DFARS, and NMCARS clauses. This clause book also implements DON Control Plan for Component Clauses. The control plan established, for Navy and Marine Corps contracting activities, "a system of controls for the use of clauses other than those prescribed in FAR or DFARS" (NMCARS, 2015).

This publication was last updated in 2011 and requires revision to update existing component provisions and clauses, and add component provisions and clause that were approved since its last update. This publication does not contain the most recent policy changes related to the DON Control Plan for Component clauses, or ordering officer roles and responsibilities. However, the information contained in this publication is relevant to NAVSUP's mission and should be incorporated into a NAVSUP acquisition supplement once it has been updated to reflect the most current NAVSUP clause book information and guidance.

\section{(3) NAVSUP Publication 736}

NAVSUP Publication 736, Contract Closeout Guidebook is published to provide information and guidance of all interested personnel. It provides Navy activities with information to assist in the closeout of contracts whether administration is retained or assigned to the Defense Contract Management Agency. The contract closeout guide is intended to provide standardized procedures to those who are responsible for contract closeout at all NAVSUP Enterprise contracting activities. It outlines the steps that 
contract specialists, and contracting officers should take in closing purchase orders, task orders, delivery orders, and contracts. It also provides for uniform steps to be follow in reporting closeout status. The guide also provides useful contract closeout web sites.

This publication was last updated in May 2011 and does not reflect the most recent policy changes related to contract closeout procedures. The information contained in this publication is relevant to NAVSUP's mission and should be incorporated into a NAVSUP acquisition supplement once it has been updated to reflect the most current information and guidance pertaining to NAVSUP contract closeout.

\section{(4) NAVSUP Publication 738}

NAVSUP Publication 738, Ordering Officer Guidebook, is published to provide ordering activities and ordering officers a clear understanding of the duties and responsibilities that fall under the cognizance of the ordering officer and makes distinctions between ordering officer roles and the roles of others in the ordering process. The guidebook sets forth standards for training, documentation, and oversight for ordering activities and ordering officers. The guidebook is designed to provide knowledge and skills necessary for ordering officers to place delivery or task orders against fixed priced contracts and agreements and to assist contacting offices in utilizing the Indefinite Delivery Type Contract. It includes information regarding covering the entire acquisition process (e.g. receipt of purchase requests, determination of contract type, placement of orders, final invoicing, and closeout of orders).

This publication was last updated in 2007 and does not reflect the most recent policy changes related to ordering officer roles and responsibilities. The information contained in this publication is relevant to NAVSUP's mission and should be incorporated into a NAVSUP acquisition supplement once it has been updated to reflect the most current information and guidance pertaining to NAVSUP ordering officers. 
THIS PAGE INTENTIONALLY LEFT BLANK 


\section{FINDINGS AND RESULTS}

Data in nine instructions, identified in Table 1, were reviewed and analyzed. Five of the nine acquisition related instructions have been identified by the Directorate as not current, and requiring review and update. Table 1 identifies each instruction and lists the issue dates or dates of the most recent updates to each instruction. Some of the information currently contained in these instructions were found to be outdated, obsolete, and superseded by more recent changes in DOD and DON acquisition policy.

Information contained in some policy letters was found to be inconsistent with information contained instructions and publications on the same subject. For example, a policy letter was recently issued in 2014, to provide guidance regarding Technical Direction, however there were no efforts made to update the corresponding Technical Direction Component Clause which was created in 1992 and is contained in NAVSUP Publication 592. This result is guidance in the policy letter that is inconsistent with the directions of the Component clause.

The NAVSUP Publications listed in Table 6 were reviewed for relevancy. All of the publications listed are relevant to NAVSUP's mission; information contained in them, however, is not current.

NAVSUP has issued more than 142 acquisition related documents in the form of policy letters and directives that provide guidance that supplements the FAR, DFARS, and NMCARS. These documents provide procurement policy, guidance, and information that the acquisition workforce must be knowledgeable of in the performance of their duties. The acquisition workforce refers to these documents for information and guidance regularly. The acquisition workforce can access any of these documents electronically, via the NLL. However, the current process for obtaining and reviewing this information and guidance, when needed, is cumbersome and an inefficient method of providing acquisition related procedures, guidance, and information to the acquisition workforce.

Under the current business practice, employees must search the reference library of policy letters on the NLL to determine if policy exists on a particular subject, then, 
access the documents once the determination has been made. Many of the instructions and publications refer readers to additional instructions and publications, and often reference specific policy letters. These documents do not provide hyperlinks for quick linkage to noted references, which leads to additional time expended shifting from one policy letter or directive to another.

The information provided above represents a weakness that exists within one of NAVSUP's current business processes. Acquisition related policy letters and directives pertinent to the mission were identified and reviewed for relevancy. Based on the results of this analysis, a different approach to maintaining and communicating supplemental acquisition related information is justified. 


\section{CONCLUSION AND RECOMMENDATIONS}

\section{A. CONCLUSION}

A proficient acquisition workforce is a workforce that has the necessary tools available to them when needed. When questions arise, the workforce needs to know where to find the answers. To effectively support the acquisition workforce, resources like acquisition regulations and supplements, policy letters, and directives must be current and accessible, well organized, and the process for searching them must be efficient. It is important that NAVSUP communicates its acquisition business practices across the NAVSUP Enterprise through efficient and effective communication channels. A NAVSUP acquisition supplement is one step towards better communication with NAVSUP NFCS activities.

Information management requires efficiently and effectively capturing, managing, preserving, storing and delivering accurate information to people at the right time. There is room for improvement throughout DOD in the area of information management. "The Navy collects more information than the Library of Congress," stated United States Secretary of the Navy, Ray Mabus, during his speech at the Navy League's 2015 SeaAir-Space Exposition, April 2015. He discussed the challenges the Navy faces with managing, controlling, and using all of the information that is collected. "Processes will only succeed if adequately skilled and motivated employees supplied with accurate and timely information are driving them" (Cavanaugh et al., 1999).

Development and use of acquisition supplements is a best practice used within agencies throughout the DOD. Other contracting activities like the Naval Sea Systems Command, Naval Air Systems Command, Space and Warfare Command, and Naval Facilities Engineering Command have developed acquisition handbooks, guidebooks and supplements to streamline their process of communicating guidance to their acquisition workforce. Additionally, best practices across the DOD include ensuring compliance, consistency, transparency, quality, accountability and responsibility exists within the 
acquisition community. Communicating acquisition policy and information efficiently and effectively will ensure that these best practices continue to evolve.

\section{B. RECOMMENDATIONS}

Based on my research, I recommend that NAVSUPSYSCOM HCA streamline its method of maintaining and communicating acquisition related information to its contracting workforce by creating a single repository for NAVSUP acquisition related policy letters and directives. Consolidation of these documents into a single NAVSUP acquisition supplement will improved the current business practice of communicating NAVSUP policy, guidance and information via 155 different documents that must be looked up and reviewed independently.

Development and use of a NAVSUP acquisition supplement would provide a more effective and efficient process for supplementing the FAR, DFARS, and NMCARS guidance, and communicating additional policy and information to the acquisition workforce. A considerable number of existing policy letters and directives contain information that is not current. Information contained in these policy letters and directives should be revised prior to including it in an acquisition supplement. NAVSUP should develop a method and schedule for periodically identifying policies and guidance that warrant revision or removal because they are no longer justified or necessary.

This project was intended to deliver a developed NAVSUP acquisition supplement that included relevant data incorporated from NAVSUP's existing acquisition policy letters and directives. After review and analysis, I concluded that the data

contained in those documents should be reviewed and verified for accuracy by NAVSUP's Contracting Management Directorate SMEs before being incorporated into an acquisition supplement. 


\section{PROPOSED ACQUISITION SUPPLEMENT}

Prior to consolidation of existing policy letters and directives into an acquisition supplement, I recommend that SME's within the NAVSUP Contracting Management Directorate review the information contained in each policy letter and directives and document needed changes. To successfully translate strategy into action, I recommend that the NAVSUPSYSCOM Contracting Management Directorate develop a supplement using the following phased approach shown in Table 7.

Table 7. NAVSUP Acquisition Supplement Development Process

\begin{tabular}{|l|l|}
\hline \multicolumn{2}{|c|}{ NAVSUP Acquisition Supplement Development Process } \\
\hline Phase I & $\begin{array}{l}\text { Incorporate the most current information that pertains to relevant instructions into } \\
\text { the draft supplement }\end{array}$ \\
\hline Phase II & $\begin{array}{l}\text { Incorporate the most current information that pertains to relevant policy letters } \\
\text { into the draft supplement }\end{array}$ \\
\hline Phase III & Revise relevant publications and add them to the acquisition supplement Annex \\
\hline Phase IV & $\begin{array}{l}\text { Forward draft supplement to the NFCS Chief Contracting Officers, Deputies, and } \\
\text { acquisition policy representatives for review and comments }\end{array}$ \\
\hline Phase V & $\begin{array}{l}\text { Make final revisions to the supplement and obtain approval of the NAVSUP } \\
\text { ACOM for Contracting }\end{array}$ \\
\hline Phase VI & Post the supplement to the NLL and Contracting Knowledge website \\
\hline Phase VII & $\begin{array}{l}\text { Remove applicable policy letters, and instructions that have been incorporated } \\
\text { into the acquisition supplement from the NLL }\end{array}$ \\
\hline
\end{tabular}

To the extent possible, the format, arrangement and numbering structure of the acquisition supplement should emulate the FAR. Subdivisions below the section and subsection levels may differ and should be relevant to NAVSUP acquisition policy guidance, and information. The supplement should be maintained by the NAVSUP Contract Management Directorate. Proposed changes to or deviations from the supplement, along with rationale for the changes or deviations should be coordinated with the requester's local chain of command and submitted to NAVSUP HQ, Contracting Management Directorate, Code N7 via email at central mailbox, NAVSUPHQN72RPT@navy.mil. The supplement should also provide hotlinks to 
specific sections within the supplement when they are referenced via hyperlinks. NAVSUP forms referenced in the supplement should be contained in an annex of forms. The primary content of the supplement will include relevant information incorporated from NAVSUP's 155 policy letters and 13 directives. The acquisition template Table of Contents depicted in the Appendix provides an example of where some of the existing supplemental information should be documented.

\section{SUMMARY}

The goal of this project was to identify, research, and address NAVSUPSYSCOM's business process for providing supplemental FAR, DFARS, and NMCARS guidance, and communicating NAVSUP acquisition related policy, guidance, and information to the acquisition workforce. My goal was to answer the primary question related to improving a business process. This project focused on the process for effectively and efficiently communicating acquisition policy, guidance and information to NAVSUP's NFCS activities. Chapter I discussed NAVSUPSYSCOM's current process of communicating acquisition related information to its acquisition workforce and the development of an acquisition supplement to streamline the process. Chapter II discussed the DAR system as a means of disseminating acquisition rules and regulations. Chapter III is a review and analysis of the data currently available and accessible to the NFCS. It depicts 155 different documents that the acquisition workforce must access to review NAVSUP policies and directives. Chapter IV discusses findings and results of the data and analysis conducted as part of this project.

I have recommended a new business practice that, if used, will streamline NAVSUP's business practice of communicating supplemental FAR, DFARS, and NMCARS guidance, and NAVSUP policy, guidance, and information, via 155 individual documents. A focus area of NAVSUP's Commander's Guidance for 2015 includes “ease of use for the systems and tools required to meet our mission" (NAVSUP, n.d, p. 2). The acquisition environment is constantly changing, and the NAVSUPSYSCOM should continue to take action to "simplify the workforce experience in accessing the systems, tools, and information used day-to-day" (NAVSUP, n.d., p. 2). 
APPENDIX. ACQUISITION SUPPLEMENT TEMPLATE

\section{NAVAL SUPPLY ACQUISITION SUPPLEMENT (NSAS) JANUARY 20XX Edition}


Table of Contents

\title{
PART 1 FEDERAL ACQUISITION REGULATIONS SYSTEM
}

\author{
SUBPART 1.1-PURPOSE, AUTHORITY, ISSUANCE \\ 1.101 Purpose \\ 1.103 Authority \\ 1.104 Applicability \\ 1.107 Certifications \\ 1.170 Peer reviews (NAVSUPINST 4200.83H)
}

\section{SUBPART 1.3-AGENCY ACQUISITION REGULATIONS}

1.303 Publication and codification

1.304 Agency control and compliance procedures

\section{SUBPART 1.4-DEVIATIONS FROM THE FAR}

1.402 Policy

1.403 Individual deviations

1.404 Class deviations

\section{SUBPART 1.6-CAREER DEVELOPMENT, CONTRACTING AUTHORITY,} AND RESPONSIBILITIES

1.601 General.

1.601-90 Department of the Navy authorities and responsibilities

1.602 Contracting officers

1.602-1 Authority

i. NFCS Contracting Authority and Responsibility (NAVSUPINST 4200.81G)

ii. Procedures for Requesting Contracting Authority

iii. Contracting Authority and Responsibility for Afloat Units

iv. Contracting Officer and Ordering Officer Appointments

v. HCA Delegation of Authority

1.602-2 Ordering Officers (NAVSUP Ordering Officer Guidebook)

1.602-3 Ratification of unauthorized commitments

1.603 Contracting Officer Warranting Program (NAVSUPINST 4200.102)

1.604 Contracting Officer's Representatives (NAVSUPINST 4205.3E)

1.690 Requirements to be met before entering into contracts

1.690-1 Contracting and Business Clearance Procedures and Approvals (NAVSUPINST 4200.83H)

1.691 Procurement management oversight (NAVSUPINST 4200.82F)

1.7 Determinations and Findings (NAVSUPINST 4200.83H)

\section{PART 2 DEFINITIONS OF WORDS AND TERMS}

SUBPART 2.1-DEFINITIONS

2.101 Definitions. 
PART 3 IMPROPER BUSINESS PRACTICES AND PERSONAL CONFLICTS OF INTEREST

PART 4 ADMINISTRATIVE MATTERS

SUBPART 4.6-CONTRACT REPORTING (NAVSUPINST 4200.84K)

SUBPART 4.8-GOVERNMENT CONTRACT FILES

4.802 Contract files. (NAVSUP PUB 736 NAVSUP Contract Closeout)

SUBPART 4.70-UNIFORM PROCUREMENT INSTRUMENT

IDENTIFICATION NUMBERS

PART 5 PUBLICIZING CONTRACT ACTIONS

SUBPART 5.4-RELEASE OF INFORMATION

PART 6 COMPETITION REQUIREMENTS

SUBPART 6.3-OTHER THAN FULL AND OPEN COMPETITION

6.303 Justifications (NAVSUPINST 4200.83H)

SUBPART 6.5-COMPETITION ADVOCATES (NAVSUP PL 14-005)

PART 7 ACQUISITION PLANNING

SUBPART 7.1-ACQUISITION PLANS

7.170 Acquisition Planning Documentation (NAVSUPINST 4200.83H)

PART 8 REQUIRED SOURCES OF SUPPLIES AND SERVICES

SUBPART 8.7-ACQUISITION FROM NONPROFIT AGENCIES EMPLOYING PEOPLE WHO ARE BLIND OR SEVERELY DISABLED

SUBPART 8.74-ENTERPRISE SOFTWARE AGREEMENTS

PART 9 CONTRACTOR QUALIFICATIONS

PART 11 DESCRIBING AGENCY NEEDS

PART 12 ACQUISITION OF COMMERCIAL ITEMS

PART 13 SIMPLIFIED ACQUISITION PROCEDURES

13.003 Policy (Hyperlink to NAVSUPINST 4200.85) 


\section{PART 14 SEALED BIDDING}

PART 15 CONTRACTING BY NEGOTIATION

SUBPART 15.6-UNSOLICITED PROPOSALS

15.6 Procedures for Processing Unsolicited Proposals (NAVSUPINST 4200.96B)

PART 16 TYPES OF CONTRACTS

PART 17 SPECIAL CONTRACTING METHODS

SUBPART 17.1-MULTI-YEAR CONTRACTING

SUBPART 17.2-OPTIONS

SUBPART 17.5-INTERAGENCY ACQUISITIONS

17.502 Procedures.

17.502-1 General.

17.502-2 The Economy Act (NAVSUPINST 4200.8H)

SUBPART 17.6 BRIDGE CONTRACT ACTIONS (PL 14-008)

SUBPART 17.7- INTERAGENCY ACQUISITIONS: ACQUISITIONS BY NONDEFENSE AGENCIES ON BEHALF OF THE DEPARTMENT OF DEFENSE

SUBPART 17.74-UNDEFINITIZED CONTRACT ACTIONS

SUBPART 17.78 - CONTRACTS OR DELIVERY ORDERS ISSUED BY A NONDOD AGENCY

PART 18 EMERGENCY ACQUISITIONS

SUBPART 18.1 NAVY CONTINGENCY CONTRACTING (Include Hyperlink to NAVSUPINST 4230.37D)

PART 19 SMALL BUSINESS PROGRAMS

PART 22 APPLICATION OF LABOR LAWS TO GOVERNMENT ACQUISITIONS

PART 23 ENVIRONMENT, ENERGY AND WATER EFFICIENCY, RENEWABLE ENERGY TECHNOLOGIES, OCCUPATIONAL SAFETY, AND DRUG-FREE WORKPLACE 
PART 24 PROTECTION OF PRIVACY AND FREEDOM OF INFORMATION

PART 25 FOREIGN ACQUISITION

PART 26 OTHER SOCIOECONOMIC PROGRAMS

PART 27 PATENTS, DATA AND COPYRIGHTS

PART 28 BONDS AND INSURANCE

PART 29 TAXES

PART 30 COST ACCOUNTING STANDARDS ADMINISTRATION

PART 31 CONTRACT COST PRINCIPLES AND PROCEDURES

PART 32 CONTRACT FINANCING

PART 33 PROTESTS, DISPUTES, AND APPEALS

PART 34 MAJOR SYSTEM ACQUISITION

PART 35 RESEARCH AND DEVELOPMENT CONTRACTING

PART 36 CONSTRUCTION AND ARCHITECT-ENGINEER CONTRACTS

PART 37 SERVICE CONTRACTING

PART 39 ACQUISITION OF INFORMATION TECHNOLOGY

PART 41 ACQUISITION OF UTILITY SERVICES

PART 42 CONTRACT ADMINISTRATION AND AUDIT SERVICES

PART 43 CONTRACT MODIFICATIONS

PART 45 GOVERNMENT PROPERTY

PART 46 QUALITY ASSURANCE

PART 47 TRANSPORTATION

PART 48 VALUE ENGINEERING

PART 49 TERMINATION OF CONTRACTS 
PART 50 EXTRAORDINARY CONTRACTUAL ACTIONS AND THE SAFETY ACT

PART 51 USE OF GOVERNMENT SOURCES BY CONTRACTORS

PART 52 SOLICITATION PROVISIONS AND CONTRACT CLAUSES

SUBPART 52.1-INSTRUCTIONS FOR USING NAVSUP PROVISIONS COMPONENT CLAUSES

SUBPART 52.2 TEXTS OF PROVISIONS AND CLAUSES (NAVSUP PUB 592, Clause Book)

ANNEX 1 - JUSTIFICATION AND APPROVAL ANNEX 2 - BUSINESS CLEARANCE MEMORANDUM

ANNEX 3 - NFCS GUIDES FOR CONDUCTING PPMAP REVIEWS (From NAVSUPINST 4200.82F)

ANNEX 4 - NAVSUP CONTRACT CLOSEOUT GUIDEBOOK

ANNEX 5 - BRIDGE CONTRACT APPROVAL AND REPORTING

ANNEX 6 - CONSOLIDATED UNDEFINITIZED CONTRACT ACTION (UCA) MANAGEMENT REPORT

ANNEX 7 - NAVSUP CLAUSE BOOK

ANNEX 8 - ORDERING OFFICER GUIDEBOOK

ANNEX 9 - AWARD FEE AND INCENTIVE FEE REPORTING

ANNEX 10 - HUSBANDING AND ORDERING OFFICER GUIDE

ANNEX 11 - DELEGATION OF CONTRACTING AUTHORITY

ANNEX 12 - FORMS

ANNEX 13 - REPORT EQUIREMENTS

(END TEMPLATE) 


\section{LIST OF REFERENCES}

Belton, C. M. (2013, February 20). Defense Acquisition Regulations System (DARS):

The rule-making process, how it works and how you can get involved [PowerPoint].

Bennington, M. D. (2015, May 06). NAVSUP Contracting Management [PowerPoint].

Cavanaugh, J. J., Lloyd, R., Logan, S., Sade, M., Schoenberg, A., \& Wheeler, E. (1999). The balanced scorecard for managing procurement performance. Contract Management, (February), 12-16.

Core certification standards. (n.d.). Retrieved March 23, 2015 from http://icatalog.dau.mil/onlinecatalog/CareerLvl.aspx?lvl=1\&cfld=3

Defense Acquisition University. (n.d.). Retrieved November 7, 2014, from https://acc.dau.mil/CommunityBrowser.aspx?id=388741\&lang=en-US

Defense Contract Audit Agency. (n.d.). Retrieved June 15, 2015 from http://www.dcaa.mil/dfars.html

Defense Federal Acquisition Regulation Supplement, 48 C.F.R. § 2 (2015). Retrieved from http://farsite.hill.af.mil/vfdfara.htm

Defense Procurement and Acquisition Policy. (2015). Retrieved from http://www.acq.osd.mil/dpap/

DFARS operating guide. (2015, January). Retrieved from http://www.acq.osd.mil/dpap/dars/docs/DFARS_Operating_Guide_January_ 2015.pdf

Federal Acquisition Regulation, 48 C.F.R. $§ 1$ (2015). Retrieved from http://www.secnav.navy.milrda/Pages/PolicyGuidance.aspx

Frieson, Gloria. (2014, December 11). Best practices in acquisition policy [Webinar]. Retrieved from https:/www.gotovao.com/index.cfm?action=comment\&id= 0390055393000443

General Services Administration. (2015). Retrieved from http://www.gsa.gov/ portal/category/21879

Naval Logistics Library. (2015). Retrieved from https://nll2.ahf.nmci.navy.mil/com.cfm

Naval Supply Systems Command. (2003, May). Contract request preparation. (NAVSUP Publication 547). Mechanicsburg, PA: Author. 
Naval Supply Systems Command. (2005, April 25). Department of the Navy simplified acquisition procedures (NAVSUP Instruction 4200.85D). Mechanicsburg, PA: Author.

Naval Supply Systems Command. (2007, June). Ordering officer guide (NAVSUP Publication 738). Mechanicsburg, PA: Author.

Naval Supply Systems Command. (2011a, June 01). Navy Contingency Contracting Program (NAVSUP Instruction 4230.37D). Mechanicsburg, PA: Author.

Naval Supply Systems Command. (2011b, January). NAVSUP clause book (NAVSUP Publication 592). Mechanicsburg, PA: Author.

Naval Supply Systems Command. (2011c, January). NAVSUP contract closeout guidebook. (NAVSUP Publication 736). Mechanicsburg, PA: Author.

Naval Supply Systems Command. (2012a, January 27). Naval Supply Systems Command, Navy Field Contracting System authority and responsibility. (NAVSUP Instruction 4200.81G). Mechanicsburg, PA: Author.

Naval Supply Systems Command. (2012b, December 18). Naval Supply Systems Command contracting and business clearance procedures and approvals (NAVSUP Instruction 4200.83H). Mechanicsburg, PA: Author.

Naval Supply Systems Command. (2012c, January 27). Procurement Management Assessment Program (NAVSUP Instruction 4200.82F). Mechanicsburg, PA: Author.

Naval Supply Systems Command. (2014a, August 24). Contract reports. (NAVSUP Instruction 4200.84K). Mechanicsburg, PA: Author.

Naval Supply Systems Command. (2014b, May 27). Contracting officer's representative (NAVSUP Instruction 4205.3E). Mechanicsburg, PA: Author.

Naval Supply Systems Command. (2014c, August 22). NAVSUP Contracting Officer Warranting Program (NAVSUP Instruction 4200.102). Mechanicsburg, PA: Author.

Naval Supply Systems Command. (2014d, November 24). Procedures for processing unsolicited proposals (NAVSUP Instruction 4200.96B). Mechanicsburg, PA: Author.

Naval Supply Systems Command. (2015). Retrieved from https://www.navsup.navy.mil/navsup

NAVSUP commander's guidance/2015. (2015). Retrieved March 23, 2015 from https://www.navsup.navy.mil/navsup/2015-commandersguidance.pdf 
NAVSUP Contracting Knowledge. Retrieved from https://www.navsup.navy.mil/cks

NAVSUP Contracting Management. (2015). Retrieved from https://www.navsup.navy.mil/navsup/ourteam/navsup/n7

NAVSUP Enterprise Contracting Plan. (2015). Retrieved from NAVSUP Contracting Management Directorate Database

NAVSUP, Our team (n.d.). Retrieved June 16, 2015, from https://www.navsup.navy.mil/navsup/ourteam/navsup

NAVSUP, Senior contracting experts from across the NAVSUP enterprise meet. (2014). Retrieved from http://www.navy.mil/submit/display.asp?story_id=84602

Navy Marine Corps Acquisition Regulation Supplement. (2015). Retrieved from http://www.secnav.navy.mil/rda/Pages/PolicyGuidance.aspx

Policy \& guidance. (n.d.). Retrieved June 16, 2015, from http://www.secnav.navy.mil/rda/Pages/PolicyGuidance.aspx 
THIS PAGE INTENTIONALLY LEFT BLANK 


\section{INITIAL DISTRIBUTION LIST}

1. Defense Technical Information Center

Ft. Belvoir, Virginia

2. Dudley Knox Library

Naval Postgraduate School

Monterey, California 